\title{
Kartacalı Hannon ve Batı Afrika Kıyılarına Seyrüsefer
}

\author{
The Carthaginian Hannon and his Voyage to the West Coast \\ of Africa
}

Hellence Aslından Çeviri ve Notlar: Erkan KURUL

open 2 access journals

Makale Künyesi
PHASELIS: Disiplinlerarası Akdeniz Araştırmaları Dergisi’nde bulunan içeriklerin tümü kullanıCılara açık, serbestçe/ücretsiz "açık erişimli” bir dergidir. Kullanıcılar, yayıncıdan ve yazar(lar)dan izin almaksızın, dergideki makaleleri tam metin olarak okuyabilir, indirebilir, dağıtabilir, makalelerin çıktısını alabilir ve kaynak göstererek makalelere bağlantı verebilir.

PHASELIS: Disiplinlerarası Akdeniz Araştırmaları Dergisi uluslararası hakemli elektronik (online) bir dergi olup değerlendirme süreci biten makaleler derginin web sitesinde (journal.phaselis.org) yıl boyunca ilgili sayının içinde (Volume I: Ocak-Aralık 2015) yayımlanır. Aralık ayı sonunda ilgili yıla ait sayı tamamlanır.

Dergide yayımlanan eserlerin sorumluluğu yazarlarına aittir.

E. Kurul, "Kartacalı Hannon ve Batı Afrika Kıyılarına Seyrüsefer". Phaselis I (2015) 231-260.

DOI: $10.18367 /$ Pha.15012

Kabul Tarihi: 14.05.2015 | Online Yayın Tarihi: 30.06.2015

Editör Phaselis Research Project

www.phaselis.org 


\title{
Kartacalı Hannon ve Batı Afrika Kıyılarına Seyrüsefer
}

\author{
The Carthaginian Hannon and his Voyage to the West Coast of Africa
}

Hellence Aslından Çeviri ve Notlar: Erkan KURUL*

"Hannon'un keşif seyahati

Kartaca denizciliğinin muhtemel en büyük başarısıdı ve kesinlikle de deniz yoluyla yapılmış olan antik keşif seferlerinin en bilineniydi"1 ${ }^{1}$.

\section{Kartaca'nın Denizcilik Tarihi: Genel Görünüm}

Fenikeliler ile en önemli kolonilerinden biri olan Kartacalılar hakkındaki sorular ve bu sorulara aranan cevaplar bilim dünyasında daima büyük bir merak uyandırmıştır. Bu merak perspektifinde Kartacalılar gerek ticari kimlikleri ve zenginlikleri, gerek sosyo-kültürel yaşamları ve toplumsal ritüelleri gerekse de edebi yazın gelenekleriyle köklü araştırmaların odağı haline gelmişlerdir². Yapılan bu inceleme ve çalışmaların büyük çoğunluğunda denizci bir millet olarak mercek altına alınan Fenikeliler ile Kartacalıların denizaşırı kolonicilik hareketleriyle birlikte şekillenen emtia hacimleri ve ekonomik faaliyetleri konu edinilmektedir. Bu incelemede Kartacalılar farklı bir bakış açısıyla ele alınmakla birlikte, onların M.Ö. V. yüzyıl başlarında (bazı araştırmacılara göreyse M.Ö. VI. yüzyıl sonlarında) yerel önderleri (ya da resmi-hukuki bir devlet görevlisi?) Hannon öncülüğünde başkentleri Kartaca'dan başlayarak Batı Afrika sahilleri boyunca düzenledikleri -coğrafi keşif ve aynı zamanda da kolonizasyon hareketi niteliğindeki- bir deniz yolculuğu ele alınmaktadır. Kartacalılar bu deniz yolculuğu esnasında kayıt altına aldıkları seyir defterlerini ilk olarak kendi dillerinde yazıya geçirmişlerdir. Daha sonra ise bu kayıtlar özetlenerek Hellence'ye çevrilmiştir ${ }^{3}$. Elinizdeki bu çalışmada bir periplus (deniz yolculuğu seyahatnamesi-keşif seferi raporu, seyrüsefer tutanakları) biçiminde günümüze ulaşmış olan metnin Latince ${ }^{4}$, Ingilizce ${ }^{5}$ ve Almanca ${ }^{6}$ edisyonlarıyla karşılaştırılmak suretiyle, içeriği hakkında bir ön bilgilendirmede bulunulmuş ve Türkçe'ye kazandırılmıştır.

* $\quad$ Arş. Gör., Akdeniz Uygarlıkları Araştırma Enstitüsü, Akdeniz Eskiçağ Araştırmaları Anabilim Dalı, Antalya. erkankurul@akdeniz.edu.tr.

1 M. Cary ve E. H. Warmington tarafından kaleme alınan "The Ancient Explorers" isimli eserde (Cary Warmington 1929, 47) Hannon ve periplus'una yönelik yapılan bu aktarım modern literatürde söz konusu metin üzerinde çalışmalar yürüten neredeyse bütün araştırmacıların hem fikir olarak belirttiği bir düşünceyi yansıtması bakımından önem arz etmektedir.

2 Moscati 2004, 27.

3 Mund-Dopchie 2003, 49.

4 Mullerus 1990, 1-14.

5 Warmington 1960, 62-64; Schoff 2014, 1-3.

6 Bayer 1993, 346-353. 
Bu doğrultuda, Kartaca'nın denizcilik odaklı tarihsel gelişiminin ana hatlarıyla bilinmesi, Hannon'un keşif yolculuğunun ve akabinde yazıya geçirdiği seyir kayıtlarının-tutanaklarının daha ayrıntılı bir biçimde algılanabilmesi açısından önem arz etmektedir. Kartaca'nın kuruluşu ve gelişimiyle ilgili bilgi veren arkeolojik bulgular, antik kaynaklar, mitograflar ve modern araştırma külliyatının geneline göz atılacak olduğunda, uygarlığa başkentlik yapan Kartaca kentinin ilk olarak bir Fenike kolonisi ${ }^{7}$ statüsünde, M.Ö. 814/ 813 yılları arasında Tyros'dan gelen kolonistler tarafından iskân edilmiş olduğ ${ }^{8}$ belirtilmektedir ${ }^{9}$. Kuruluşundan itibaren hızlı bir biçimde gelişen ve uygulamış olduğu Thallassokrasi politikası çerçevesinde Batı Akdeniz'de giderek söz sahibi olmaya başlayan Kartaca, dominyonu Fenikeli ve de rekabet içinde bulunduğu Hellen-Hellen kökenli Sicilyalı denizciler ile birlikte ortak çıkarları doğrultusunda Akdeniz genelindeki denizcilik faaliyetlerini ivmeli bir biçimde geliştirerek sürdürmüştür ${ }^{10}$. Bunun akabinde M.Ö. VI. yüzyılın başlarında Fenike'nin başkenti Tyros'un Asurlular tarafından yıkılmasıyla birlikte Kartaca Fenikelilerin Doğu Akdeniz'deki gücünün Batı Akdeniz'deki varsılı ve yürütücüsü haline geldi ${ }^{11}$. M.Ö. V. yüzyıla gelindiğindeyse, uzak batıda, İspanya sahilleri boyunca sürdürülen denizcilik faaliyetlerinin ve deniz ticaretinin gidişatını kısmen de olsa Kartacalılar hükümleri altına aldılar ${ }^{12}$. M.Ö. IV. yüzyılda Kartaca-Fenike ilişkileri devam etmekle birlikte ilerleyen yüzyılla birlikte Kartaca giderek siyasi, ekonomik ve askeri açılardan da ön plana çıkmaya başladı. Öyle ki M.Ö. III. yüzyılın başlarında Akdeniz'in ticaret başkentliğine kadar yükseldi' ${ }^{13}$. Bu durum bölge karasularındaki gücünü iyiden iyiye arttıran ve Akdeniz hâkimiyeti konusunda başka bir rakibe fırsat vermek istemeyen Roma'nın dikkatini Kartaca'nın üzerine çekti ${ }^{14}$.

Bu süreçte artık Akdeniz'in batısındaki karasularının kıta sahanlığı için iki baskın kuvvet bulunmaktaydı ve denizlerdeki bu hâkimiyet meselesi ya güçler arasında eşit bir biçimde paylaşılarak anlaşmayla çözülecek ya da rakiplerden biri diğerini egale edinceye kadar devam edecekti. Bu doğrultuda M.Ö. III. yüzyııı başlarında henüz uygulamaya geçirmiş olduğu denizcilik faaliyetleri genelinde denizlerde gittikçe güç ve otorite kazanmaya başlayan Roma ve yaklaşık beş yüzyıllık gemicilik tecrübesine sahip olan Kartaca donanmalarının Akdeniz hâkimiyeti odakı ilk karşılaşması (I. Kartaca Savaşı kapsamında) M.Ö. 260 yılında Sicilya açıklarındaki Mylae karasularında gerçekleşti. Savaş Roma'nın üstünlüğüyle sonuçlandı ${ }^{15}$ ve bu tarihle birlikte Roma Sicilya Adası'nın kuzey kıyıları açıklarındaki ilk karasuyu ve kıta sahanlığı hâkimiyet alanını ilan etti ${ }^{16}$. Dört yıl sonra, M.Ö. 256'da Sicilya'nın güney kıyısındaki Eknomos Burnu açıklarında gerçekleşen ve antikçağ tarihinde bilinen en kalabalık asker nüfusuna sahip donanmaların karşı karşıya geldiği diğer bir deniz muharebesi de Roma'nın üstünlüğüyle sonuçlandı. Böylece

7 Antikçağda koloniyi kuran ana kent ile kolonileştirdiği kentler arasındaki ilişkiler sadece kültürel, sosyal ve dini temelli kalmamakta; savaş zamanları dışında sıklıkla yurttaşık haklarının karşııılı değişimi ya da ithalatihracat vergilerinin iki tarafı kaldırılması gibi ayrıcalıkları da içermekteydi.

8

9

10 Strab. XVII. 15; lust. XVIII. 5. 1-17. 
Kartaca'nın denizlerdeki üstünlüğü artık büyük ölçüde Roma'nın eline geçmiş oldu ${ }^{17}$. Deniz hâkimiyetini eline geçiren ve bu gücünü zamanla ivmeli bir biçimde arttıran Roma'nın Kartaca karşııındaki bu rakip tutumu ve üstünlüğü Kartaca'nın mağlubiyetiyle sonuçlanan bir dizi savaş neticesinde giderek güç kaybetmesine de sebebiyet verdi. Bu savaş dizisi M.Ö. 264-241 yılları arasında gerçekleşen Birinci Kartaca Savaşı ile başlamış, M.Ö. 218-201 yılları arasında íkinci Kartaca Savaşı'yla devam etmiştir. Son savaş ise ilk iki savaş kadar uzun soluklu olmamıştır. M.Ö. 149-146 yılları arasında toplam üç yıl süren Üçüncü Kartaca Savaşı'yla bu muharebe zinciri sona ermiştir.

M.Ö. 146 yılı ilkbaharının başlarında bu medeniyete başkentlik yapan Kartaca kenti (Korinthos ile birlikte aynı yıl içinde) Publius Cornelius Scipio komutasındaki Roma lejyonlarınca tamamıyla yakılıp yıkılmış ${ }^{18}$, halkı köleleştirilmiş, topraklarıysa tuz dökülerek lanetlenmiş ve ager publicus statüsüne getirilerek kamusallaştırımışıır ${ }^{19}$. Bu suretle de Kartaca kenti ve yönetim kurumları tarih sahnesinden -fiilen- silinmiş oldu. Ancak Akdeniz hâkimiyeti odaklı düşünüldüğünde, hinterlandında oldukça verimli tarımsal arazilere ve Afrika kıtasında da stratejik bir konuma sahip olan Kartaca'nın ve genelinde de Afrika'nın sahipsiz kalması ve çoraklaştırılması Roma açısından bir dezavantaj doğurmaktaydı. Bu sebeple, İmparatorluğun uyguladığı yararcılık politikası çerçevesinde bölgenin, bölgeye hükmeden kıyı sahasının ve bu kıyı sahasında oldukça etkili bir konuma sahip kentin söz konusu geniş imkânlarının Roma'nın çıkarları doğrultusunda değerlendirilmesi gerekmekteydi. Bu politika doğrultusunda M.Ö. 146 yılında Afrika (Kartaca kenti ve yakın çevresini kapsayan bir arazi merkezinde ${ }^{20}$ ) Roma'ya bağlı bir eyalet haline getirildi. Bunu takiben yıkılmasından yaklaşık yüz sene sonra, M.Ö. 46 yılında Gaius Iulius Caesar'ın, Gnaeus Pompeius Magnus'a karşı yürüttüğü askeri faaliyetleri kapsamında bölgeye gelmesi ve M.Ö. 46/45 yılları arasında da veteran askerlerini kent civarına yerleştirmesiyle Kartaca'nın yeniden nüfuslandırıması konusunda ilk somut adım atılmış oldu ${ }^{21}$. Caesar'ın yasal varisi ve politikalarının sürdürücüsü Gaius Iulius Caesar Octavianus ise Caesar'ın tasarladığı ve uygulamaya geçirdiği; ancak kendisinin M.Ö. 44 yılının 15 Mart'ında bir suikast sonucunda katledilmesi nedeniyle yarım kalan Kartaca'nın yeniden iskân edilmesi politikasını tamamlamak üzere eyaletleştirme faaliyetlerine Afrika'yı da dâhil etti. Bu doğrultuda M.Ö. 29 yılında Kartaca Akdeniz'in yükselmekte olan yeni güç odağı Roma Imparatorluğu'na bağlı bir koloni kenti statüsünde yeniden kuruldu ${ }^{22}$. Kent sınırları genişletilmek suretiyle M.Ö. 27 yılında baştan yapılandırılan ${ }^{23}$ Africa Eyaleti'nin (Provincia Africa Proconsularis) başkenti statüsüne getirildi ve bağlı bulunduğu eyaletle birlikte bir prokonsülün yönetimine bağlanmak kaydıyla Senatus Eyaletleri arasına girdi. Böylelikle prokonsul'lük (proconsularis) yönetimindeki kent uzunca bir süre daha bölge üzerindeki sosyo-kültürel etkisini sürdürmeye devam etti ${ }^{24}$ ve tekrardan denizlerde güç

Bagnall 2002, 9.

18 Mosley 1975, 119; Purcell 1995, 133.

19 Cic. Leg. Agr. I. 5-6; ayrıca bk. Scullard 1955, 103.

20 Hitchner 2010, 34.

21 Plut. Caes. LVII; Pomp. XI-XII; ayrıca bk. Tüner Önen 2015, 352.

22 Kurulan yeni kent Colonia Iulia Concordia Carthago ismiyle tarihsel kayıtlardaki yerini almıştır. Konu hakkında ayrıca bk. Edmondson 2006, 251; Heenan 1996, 180.

23 Fishwick 1993, 54; Gruen 2004³ , 166; Eck 2007², 124; Hitchner 2010, 35-36. Afrika eyaletindeki idari ve askeri düzenlemeler hakkında ayrıca bk. Mahjoubi 1981, 469-476. Purcell 2013, 585. 
kazanmaya başladı. Bu süreçte Augustus'tan sonra gelen Hadrianus, Antonius Pius, Marcus Aurelius ve Commodus gibi diğer Roma imparatorları da kentin kalkınmasına ve gelişmesine oldukça özen gösterdiler. Öyle ki M.S. II. yüzyılın ortalarına gelindiğinde kent Roma, Byzantion, Atina, Miletos, Syrakusa, Marsilya ve Iskenderiye gibi Akdeniz'in lider başkentlerinden ve cazibe merkezlerinden biri haline geldi ve Severuslar Hanedanı zamanında da gücünün doruğuna ulaştı.

Kartaca'nın söz konusu bu üstünlüğü ve gücü M.S. 439 yılında İspanya'dan gelen Vandalların bölgeyi Roma hâkimiyetinden ayırmasına kadar (belirli aralıklarla olsa da) devam etti ${ }^{25}$. Kent M.S. $533^{26}$ yılında Doğu Roma İmparatorluğu tarafından (yeniden) fethedilene kadar Vandalların egemenliğinde kalmaya devam etti ${ }^{27}$. Doğu Roma hâkimiyetinin ardından M.S. VII. yüzyılla birlikte Afrika genelinde vuku bulan ve kent topraklarını da etkisi altına alan Arap akınlarına maruz kalmasıyla birlikte Kartaca mevcut deniz gücünü (tekrar) kaybetti ve Araplar tarafından fethedildi ${ }^{28}$. Kartaca Uygarlığı'nın kuruluşundan yıkıışına ve akabinde baştan inşa edilip Romalılaştırılmasına kadarki süreçte sahip olduğu yaklaşık bin yıllık tarihsel geçmişi (M.Ö. VIII M.S. II. yüzyıllar arası) kapsamında geride bıraktığı muazzam nitelikteki bir bilgi birikimi külliyatı ${ }^{29}$ Roma'nın (ardından Doğu Roma ve Arap-İslam Dünyası'nın) direk kullanımına açımış oldu. Bunun yanında da dolaylı yoldan, giderek gelişen ve de genişleyen Roma Imparatorluğu'nun elinde hazır bulunan bu külliyatı işleyerek yeni sosyal, siyasi, hukuki, kültürel, ekonomik ve dini yapılandırmalar oluşturmasında rol model oluşturdu.

\section{Kartacalı Hannon ve Eserine Genel Bakış}

Kartaca'nın geçirmiş olduğu bu tarihsel süreçte, M.Ö. VI. yüzyıl sonu - V. yüzyıl başı arasındaki bir zaman dilimi içerisinde Hannon ('A $v v \omega v$ ) ve onun Herakles Sütunları'nın ( $\alpha i{ }^{~ ' H \rho \alpha ́ k \lambda} \lambda \varepsilon 101 \sigma \tau \hat{\imath} \lambda \alpha$ 1, günümüzdeki adıyla Cebelitarık Boğazı) ötesine, Kuzeybatı Afrika sahili istikametinde ${ }^{30}$

25 Hydat. 115 (439); Schwarcz 2004, 53; Hitchner 2010, 36. ayrıca bk. Victor Vit. Hist. Pers. I. 8-9; Leone 2007, 154-166; Lee 2013, 116.

26 Kent M.S. 527-565 yılları arasında hüküm sürmüş olan Flavius Petrus Sabbatius lustinianus Augustus (Büyük Iustinianus) tarafından fethedilerek Doğu Roma Imparatorluğu topraklarına dâhil edilmiştir. Iustinianus'un Kartaca'yı fethi hakkında bk. Proc. de Bell. III. 20. 20-23; ayrıca bk. Pohl 2005, 463. Konu hakkında ayrıca bk. Lee 2013, 116-117.

28 M.S. 675 yılında Emevi halifesi Muaviye tarafından Tunus'a vali olarak tayin edilen Ebü'l-Muhâcir Dînâr, yedi yıl süren valiliği esnasında Kartaca şehri ve civarının fethini tamamlamıştır. Kartaca'nın İslam Dönemi'ndeki statüsü ve tarihçesi hakkında ayrıca bk. Yiğit 2012, 385-388.

Denizcilik konusunda deneyim kazanmış halkların-ulusların gemicilik konusunda kapsamlı bir bilgi birikimini arkalarında bırakmaları beklenmedik bir olgu değildir. Bu doğrultuda, denizlerde uzunca bir süre egemenlik kurmuş ve üst düzey bir tecrübe seviyesine ulaşmış ulusların-kavimlerin geleceğe yönelik bilgi aktarımları yalnızca tarihi ve coğrafi alanlarda değil, hukuki konularda da gerçekleştirilmekteydi. Rhodos da bu kapsamda yaklaşık beş yüz yıllık (M.Ö. VII-II yüzyıllar arası) gemicilik tecrübesine sahip thalassokrasik bir rejim olarak oldukça kapsamlı bir deniz hukuku külliyatını gelecek uluslara miras bırakmıştır. Rhodos Denizcilik Yasaları'na ait hukuki metinler hakkında ayrıca bk. Anonym. Nom. Rhod.; Dig. XIV. 2; Kurul 2014, 527-534; 2015, 379-389.

30 Güneybatı doğrultusunda, günümüzdeki coğrafi dizininde sırasıyla: Fas, Batı Sahra, Moritanya, Senegal, Gambia, Gine-Bissau, Gine, Sierra Leone sahil hattı boyunca. L. Casson $(19792,63)$ 'de ise bu keşif seferinin Sierra Leone'den daha da ileriye gitmediği görüşünü savunmaktadır. Ancak bazı araştırmacılara göre de (örn. Roller 2006, 31) söz konusu bu keşif yolculuğu daha da ileriye, Liberya, Fildişi Sahili, Gana, Togo, Benin, Nijerya, Kamerun ve Ekvator Ginesi kıyı şeridini kapsayacak bir rota istikametinde ilerlemiştir. Keşif yolculuğunun güzergâhı hakkındaki farklı görüşler ve tartışmalar için ayrıca bk. Lipiński 2004, 436; Asente 2015, 99. Keşif seferindeki rotaya yönelik her iki görüşü de tamamıyla kapsayan harita için bk. Fig. 1. 
düzenlemiş olduğu seyrüsefer ( $\left.\pi \varepsilon p i ́ \pi \lambda o v \varsigma^{31}\right)$ ve bu yolculuğun seyir kayıtları, tıpkı diğer seyir tutanakları gibi ${ }^{32}$, günümüzdeki coğrafi keşiflerin tarihine ve de gelişimine ışık tutar niteliktedir. Kayıt altına alınan bu keşif seferi günlüğü de, diğer periplus'lara benzer şekilde, entelektüel gemiciler tarafından oluşturulmuştur. Zira bu tür çalışmalar antikçağda genellikle okuma yazma bilmeyen gemici-tüccarlardan ziyade denizcilik konusunda eğitimli ve de okuma yazma bilen denizciler tarafından gerçekleştirilmekteydi ${ }^{33}$. Bunlar çoğunlukla liman kitapçıkları ya da kılavuz niteliğindeki fasiküllerdi ${ }^{34}$. Diğer bir deyişle, açık deniz gemicilerine öncelikle rotaları ve bunun yanında da kıyı kentleri ve de limanlar arasındaki mesafeler, önemli nehirler ve bu nehirlerden iç kesimlerdeki kentlere ulaşılabilirlik, iklimsel faktörler, denizlerdeki yerel özellikler ve demir atılabilecek güvenli bölgeler gibi başlıklar hakkında ihtiyaç duydukları bilgileri detaylı bir şekilde sunabilen belgelerdi ${ }^{35}$. Antikçağ boyunca, denizciliğin ve de deniz ticaretinin evrimiyle orantılı olarak (söz konusu bu yaygın kullanım sahası kapsamında) Periplus yazımı edebi bir yazım geleneği olarak hızlı bir şekilde yayıldı. Akabinde bu gelenek Fenikeliler, Hellenler ve de Romalılar başta olmak üzere denizcilik konusunda deneyim kazanmış ve ayrıca kabiliyet-yetkinlik sahibi halklar tarafından geliştirildi ${ }^{36}$. Öyle ki Hellenistik Dönem'in sonlarına gelindiğinde, Akdeniz'den Ege ve Karadeniz'e, Kızıldeniz'den Hazar Denizi'ne, Marmara Denizi'nden Adriyatik ve Tiren Denizlerine ve Hint Okyanusu kıyılarından da Atlas Okyanusu sahillerine ${ }^{37}$ kadar bilinen

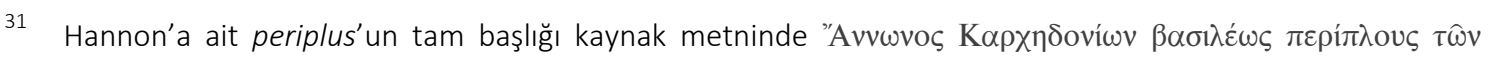
ن́ kısaltılarak kullanılmış ve kontekst bütünlüğüne uygun olarak periplus terimine yer verilmiştir.

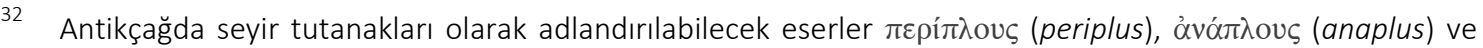
$\pi \varepsilon \rho ı ́ \gamma \eta \sigma \iota \varsigma$ (periegesis) terimleriyle başlıklandırılmaktaydılar. Bu terimlerden periplus ve anaplus genel anlamı doğrultusunda denizler üzerinden sürdürülen ve özelde kıyı hatları boyunca gerçekleştirilen seferlerin kayıtlarını kapsarken periegesis terimi ise hem karasal ve hem de sahil kesimlerine odaklı seyir hareketlerinin kayıtlarını içermekteydi.

33 Conner 2012, 223.

34 Börstinghaus 2010, 18.

35 Shahar 2004, 40

36 Periplus yazımının özellikle Hellen ve Fenike kökenli denizciler tarafından geliştirilmesinin diğer bir önemli nedeni de söz konusu iki uygarlığın M.Ö. 750-550 yılları arasındaki Büyük Kolonizasyon Dönemi esnasında özellikle deniz yolları üzerinden yoğun bir yayılma politikası uygulamış olmalarıdır. Gerçekleştirilen kolonicilik faaliyetleri sonrasında ulaşılan destinasyonlara ait verilerin bir sonraki koloninin kurulmasında rehber olarak kullanılabilecek belgelere işlenmesi gerekmekteydi ve bu ihtiyaç da mevcut seferler süresince tutulan notların periplus olarak adlandırılan belgelere aktarılması suretiyle giderilmiş oluyordu. Konu hakkında ayrıca bk. Blomqvist 1979, 55.

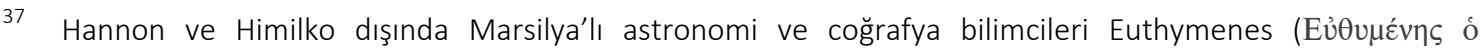

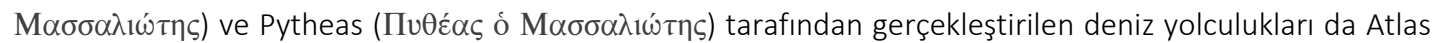
(Atlantik) Okyanusu kıyılarının keşfi açısından oldukça önemli niteliğe sahiptirler. Marsiyalı kâşiflerden ilki Euthymenes tarafından M.Ö. VI-V. yüzyıllarda Kuzeybatı Afrika sahillerine yönelik bir keşif seferi düzenlenmiş olduğu bilinmektedir. Onun bu keşif seferi sırasında yazmış olduğu periplus her ne kadar günümüze ulaşamamış olsa da antik yazarların eserin varlığına yönelik yaptıkları atıflar ve de içeriğindeki bilgilere yönelttikleri eleştiriler vasıtasıyla keşif seferi hakkında önemli birtakım bilgilere sahip olunabilmektedir. Bu bilgiler içerisinde en önem arz edeni Euthymenes'in seferinin sonlarına doğru ulaştığı ve sularının Atlantik Okyanusu'na boşaldığını belirttiği bir nehri (muhtemelen Senegal Nehri) Nil Nehri sanmış olmasıdır. Buna ek olarak Euthymenes Nil Nehri sandığı bu nehrin sularının bölgede kuvvetli bir biçimde esen Etesian rüzgârlarının etkisiyle ters akıntı oluşturduğunu ve bu suretle de (sözde) Nil Nehri'nin kabarma ve taşkınllarının Okyanus sularının taşmasından kaynaklandığını ileri sürmektedir. Bir diğer Marsiyalı kâşif Pytheas'ın M.Ö. ca. 325 yılında gerçekleştirmiş olduğu deniz seferi ise ana hatlarıyla 
dünyanın bütün karasularına keşif-araştırma seyahatlari düzenlenmiş ${ }^{38}$ ve bu denizlerokyanuslar hakkında oldukça önemli periplus'lar kaleme alınmıştı. Bunlara ek olarak irili ufaklı yüzlerce çay, dere, ırmak ve akarsular; göletler, lagünler ve göller; adalar, yarımadalar, koylar, körfezler, kıstaklar, boğazlar ve kanallar da bu keşif gezileri sırasında göz ardı edilmeyerek seyir tutanaklarına işlenmiştir. Denizcilik konusunda yukarıda belirtilen bu yarar ve önemlerine karşın antikçağdan günümüze oldukça az sayıda periplus kalmıştır; ancak var olanların (oldukça yüzeysel bir şekilde olsa da) okuyucuya ulaşabilen fragmanları dahi antikçağ tarihi coğrafyası ve denizcilik tarihi açısından yüksek bir öneme sahiptir ve de kaynak belge niteliğindedir. Bunlar belli bir zaman diliminde ve belirli bir coğrafi bölgeye yönelik kaleme alınmışlardır. Buna ek olarak denizcilikle ilgili beşeri, kültürel ve de sosyo-politik bilgi birikimini bünyelerinde barındırdıkları gibi, bu bilgilerin derlenmesinde ve yeniden yorumlanmasında da önemli bir işleve sahiptirler.

Varlı̆̆ı ilk olarak M.Ö. IV. yüzyılda yaşayan Kymeli $\operatorname{Ephoros}^{39}$ ve Aristoteles'in ardıllarından ${ }^{40}$ biri (Pseudo-Aristoteles, olasılıkla M.Ö. II. yüzyıl) tarafından beyan edilen anekdotlarla ${ }^{41}$ kanıtlanan söz konusu bu keşif seferinin düzenlenişinin ve akabinde bir periplus formunda kayıt altına alınışıın tarihlendirilmesi konusunda ilk ve en önemli bilgiyi ünlü Romalı amiral ve aynı zamanda da doğa gözlemcisi bir yazar olan Gaius Plinius Secundus'tan (Plinius Maior=Yaşlı Plinius) öğrenmekteyiz. Plinius'a göre ${ }^{42}$ Kartacalıların refah ve zenginliğinin oldukça yüksek

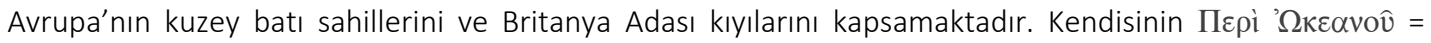
Okyanus Üzerine adlı bu eseri de günümüze ulaşamamıştı, ancak yine Pytheas'tan alıntı yapan yazarlar ya da eserinin günümüze ulaşabilmiş olan fragmanları vasıtasıyla seferin içeriği hakkında önemli veriler elde edilebilmektedir. Euthymenes hakkında bk. Branigan 1994, 1-3; Brodersen 1998b, 318-319. Euthymenes'in periplus'unda geçen (sözde) Nil Nehri hakkındaki bilgilerin antik yazarlarca eleştirilmiş olması hususunda örnek olarak ayrıca bk. Sen. Nat. IV A. 22-25. Pytheas'ın seferi hakkındaki ek bilgi, görüşler ve de içeriğindeki bilgilerin geçerliği hakkındaki tartışmalar ve eleştiriler için bk. Plin. nat. II. 77; II. 99. 217-118; Strab. II. 4. 1-2; ayrıca bk. Mills 2003, 536-537; Conner 2012, 221-222; Irby 2012, 98-99.

38 Söz konusu keşif seferlerinin düzenlenmesinde M.Ö. 750-550 yılları arasına tarihlendirilen Büyük Kolonizasyon Dönemi oldukça önemli bir etkiye sahiptir. Zira belirtilen yıllarda Hellenler Akdeniz, Karadeniz ve Marmara Denizi genelinde Platon'un da bahsettiği üzere (Phaedo 109B) "(Hellenler) bir havuzun kenarında yaşamlarını sürdüren karıncalar ve de kurbağalara benzer şekilde deniz kıyısında" yaşamaktaydılar. Bu yaşam alanları şekillendikçe Hellen denizcilerin kıyı hattı ve sahil kentleri konusundaki bellekleri giderek genişlemiş ve bu bilgi birikimi süreç içerisinde kayıt altına alınarak yazıya geçirilmiştir. Büyük Kolonizasyon Dönemi hakkında bk. Lamboley 2007, 55-64; Arslan 2010, 14-15.

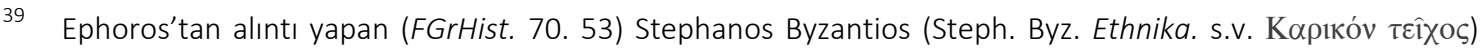
Hannon'un periplus'unda geçen kentlerden biri olan Karikon Teikhos'a yönelik bilgilendirmede bulunmaktadır. Bu bilgilendirme kapsamında Ephoros'un söz konusu periplus'u okumuş ve de muhtemelen kullanmış olabileceğine yönelik (örn. bk. Roller 2006, dn. 62) görüşler mevcuttur.

40 Aristoteles'in yaşarken kendisinin kurmuş olduğu Peripatos adlı okula mensup olan öğrenciler onun ölümünden sonra Aristoteles'in öğretilerini benimseyerek geliştirmişler ve Aristoteles'e atfedilen birçok çalışma gerçekleştirmişlerdir. Hannon ve keşif seferi hakkındaki ilk aktarımların da bu öğrencilerden biri tarafından derlendiği düşünülmektedir. Pseudo-Aristoteles hakkında detaylı bilgi için bk. Howatson 2013, 83-90.

41 Aristot. Mir. Ausc. 833a 12

42 Plin. nat. II. 168; ...et Hanno Carthaginis potentia florente circumvectus a Gadibus ad finem Arabiae navigationem eam prodidit scripto, sicut ad extera Europae noscenda missus eodem tempore Himilco = Kartaca'nın gücünün doruğuna ulaştığı zaman Hannon Gadiz'den Arabistan sınırına kadar sonucunu kaydedip yayınladığı bir seyrüsefer gerçekleştirdi, (onunla) aynı anda Himilko'da Avrupa’nın dış sahillerini keşfetmek amacıyla (başka bir) seyrüsefere gönderilmişti. 
olduğu bir dönemde Hannon isminde Kartacalı bir sufes ${ }^{43}$ Batı Afrika kıyılarının keşfedilmesi ve keşfedilen kıyılarda Kartaca hâkimiyetinde yeni koloni kentlerinin kurulması (apoikismos) ya da bölgede daha önceden de mevcut olan köylerin birleştirilmesi (synoikismos ${ }^{44}$ ) amacıyla ${ }^{45}$ bir deniz yolculuğu yapmakla görevlendirilmişti ${ }^{46}$. Onunla aynı zaman diliminde Kartacalı diğer bir sufes Himilko da ${ }^{47}$ Herakles Sütunları'ndan kuzeye doğru, ỉber Yarımadası'ndan başlayarak Britanya Adası'na kadar uzanan sahil hattı boyunca planlanan başka bir keşif seferini yönetmekteydi ${ }^{48}$. Plinius'un vermiş olduğu bu bilgi, Hannon'un deniz yolculuğunun tarihlendiril-

43 Sufes (plu: suffetes): Kartaca'nın yönetim mekanizmasının başında olan bu iki yöneticinin yetkileri Sparta'daki iki krallı yönetim sistemine ve de Roma'daki iki consul'lü hiyerarşi düzenine benzemektedir. Söz konusu yönetim sisteminin başında yer alan iki sufes her yıl zenginlikleri ve kişisel erdemleri-meziyetleri göz önüne alınarak başa getirilmekteydi. Bunların yetkileri yönetimde oldukça aktif rol oynayan ve Kartaca'nın varlıklı tüccar zümresinden oluşan ihtiyar heyeti tarafından kontrol edilmekteydi. Kartaca'nın yönetim sistemi hakkında Aristoteles'in vermiş olduğu bilgi ve Kartaca ile Sparta yönetim sistemlerinin birbirleriyle mukayese edilmesi hakkında bk. Aristot. pol. 1272b. Isokrates ise Sparta ve Kartaca yönetim düzenleri

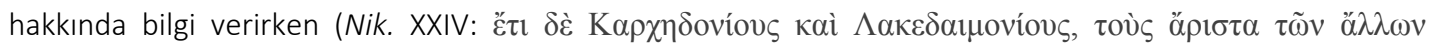

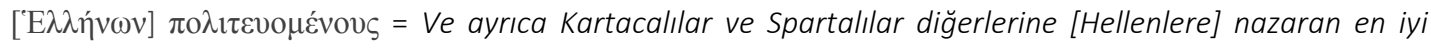
yönetilenlerdir) söz konusu iki ulusun rejiminden övgüyle bahsetmektedir. Benzer bir övgü Cicero tarafından da yapılmaktadır (rep. fr. I. 3; Nec tantum Karthago habuisset opum sescentos fere annos sine consiliis et disciplina=Kartaca (yönetimindeki) bilgelik ve disiplin olmaksızın tam tamına altı yüz yıl boyunca böylesine bir iktidara sahip olamazdı). Kartaca yönetim sistemi hakkında ayrıca bk. Polyb. VI. 51; Warmington 1981, 452-453; Scullard 1989, 487-491. Sufes hakkında daha detaylı bilgi için ayrıca bk. Hennig 1927, 378; Wolters 1952, 193; Burns 19687, 215; Brodersen 1998a, 155; Law 20027, 119; Lipiński 2004, 436; Moore 2010, 54; Scullard 2013², 144; Schoff 2014, 16, 18.

44 Antikçağda kent kurumlarının ve polis kimliğinin yapılandırılması ve bir kentin bütün yapı organlarıyla mevcudiyet kazanması üzerine iki temel prensip bulunmaktadır. Bunlardan ilki ve en yaygın olarak kullanılan bir kentin baştan yapılandırılarak kurulmasını ifade eden apoikismos (ả Bu metod herhangi bir mevcudiyeti ve belirli bir nüfusu bulunmayan coğrafi bir bölgenin iskân edilerek yerleşimcilere açılmasını ve bir koloni kent (apoikia) statüsünde varlığını sürdürmesini amaçlamaktaydı.

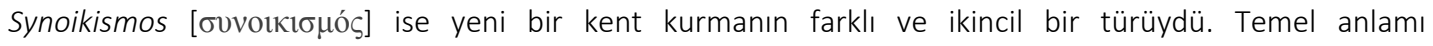
doğrultusunda, antikçağda birbirlerinden uzak ve dağınık biçimde konumlanmış olan yerel yerleşim birimlerinin, küçük hane kümelerinin ve köy-mezraların belirli bir coğrafi bütünlük içerisinde bir araya getirilerek ya da söz konusu bu iskân birimlerine çevrelerindeki başka yerleşim alanlarından nüfus aktarımı yapılarak oluşturulan kent (polis) yerleşimlerine synoikismos adı verilirdi. Bununla beraber yeni bir kentkentçik kurmanın arkasında bulunan nedenler de oldukça çeşitliydi ve genellikle politik, sosyo-kültürel, ekonomik, dini ve stratejik etmenlerden kaynaklanmakta olup oldukça karmaşık bir oluşum evresine sahiplerdi. Hellen ve Romalılar tarafından sıklıkla oluşturulan synoikismos'lar kimi zaman ticaret, kimi zaman bir bölgenin tarımsal potansiyelinden ya da doğal kaynaklarından istifade etmek, kimi zaman da bir kentte oluşan fazla nüfusu başka yere taşımak için stratejik ve askerî amaçlı da kurulmaktaydılar. Synoikismos hakkında bk. Crawford - Whitehead 1983, 42-43; Hansen 2006, 52-54; Arslan 2010, $15-16$. Apoikismos hakkında ayrıca bk. Hansen 2006, 34-35.

Falconer 1797, XIV; Smith 1877, 183.

46 Plin. nat. V. 1. 8; Marindin 1910, 266.

47 Himilko'nun düzenlediği bu sefer hakkında (kısmen de olsa, ilk dört yüz satırı özelinde) içerik bilgisi sunan ve periplus tarzında yazılmış olan Latince bir kaynak mevcuttur. Söz konusu kaynak M.S. V. yüzyılda yaşadığı düşünülen Etrurialı Postumius (?) Rufius Festus Avienus tarafından yazılmıştır. Ora Maritima (Deniz Kıyıları) başlığıyla adlandırılan bu eser dışında Doğu Roma Dönemi'ne kadar Himilko'nun seferi hakkında direk bilgi veren kaynaklar mevcut olmamakla birlikte, söz konusu keşif gezisine dolaylı yoldan yapılan birtakım atıflar bulunmaktadır. Himilko'nun seferi hakkında detaylı bilgi için bk. Avien. Ora Maritima 110-410; Roller 2006, 27-29; 2012b, 70-71. Avienus hakkında ayrıca bk. Küppers 1997, 370-371. 
mesi açısından oldukça önemlidir. Zira bu değerlendirmeden yola çıkılarak söz konusu seferin Kartaca'nın gücünün doruğa ulaştığı M.Ö. VI. yüzyıl sonu - V. yüzyıl başı arasındaki bir zaman diliminde gerçekleşmesinin yüksek ihtimalli olduğu sonucuna varılır. Bu tarihlendirme önerisi de deniz yolculuğunun gerçekleştirildiği ve akabinde bir periplus biçiminde kayda geçirildiği dönem açısından ortak görüş ${ }^{49}$-communis opinio- olarak kabul görmektedir ${ }^{50}$. Söz konusu tarihlemeyle orantılı olarak, Kartaca'da hüküm sürmüş olan sufes listeleri de kronolojik bir biçimde incelendiği takdirde, Hannon ve kardeşi? Himilko'nun sufes olarak görev yapmış oldukları tarih aralığının da (M.Ö. 490/80-440 yılları arası) periplus'un tarihlendirildiği zaman dilimiyle uyuştuğu görülmektedir ${ }^{51}$.

Bu bilgiye ek olarak, keşif seferinin tarihlendirilmesi konusunda -günümüz tarihçileri tarafından zaman zaman kanıt olarak da ileri sürülen- diğer bir önemli ipucu Herodotos'un eserinde (IV. 42-43) bulunmaktadır. Herodotos Libya'nın keşif tarihine yönelik değerlendirmelerini aktarırken Libya'nın ve de Libya kıyılarının keşfedilmesi ve Herakles Sütunları'nın aşılması hususunda bazı bilgilendirmelerde bulunmaktadır. Bu doğrultuda da M.Ö. 610-595 yılları arasında hüküm süren 26. Hanedan üyesi Mısır firavunu Nekhos II'nin emriyle M.Ö. ca. 605 senesinde gerçekleştirilerek üç yıl içinde tamamlanan ve Afrika kıyılarının büyük bir bölümünü kapsayan keşif seferine atıfta bulunmaktadır. Herodotos'un atıfta bulunduğu diğer bir sefer de Kserkses I (M.Ö. 486-465) zamanında yaşamış olan Sataspes ${ }^{52}$ tarafından M.Ö. ca. 475 yılında gerçekleştirilen ancak tamamlanamayan ve yalnızca bir keşif seferi girişimi olarak tanımlanan deniz yolculuğudur. Afrika-Libya kıyılarını kapsayan bu iki sefere Herodotos'un aktarımlarında yer verilmesi ancak Hannon'un keşif seferinden hiç bahsedilmemesi, seferin tarihlendirilmesi noktasında Hannon'un deniz yolculuğunun Herodotos'un eserinin yazılmasından hemen sonra ya da aynı zaman diliminde gerçekleştirildiğine yönelik birtakım tarihlendirme yorumlarını da beraberinde getirmektedir ${ }^{53}$.

Hannon'un Kartaca'dan başlayarak yaklaşık olarak 35 gün sürdürmüş olduğu düşünülen bu

yapılırken doğusunda da benzer keşif seyahatleri paralel yüzyıllar içerinde gerçekleştirilmekteydi. Doğudaki bu keşif seyahatleri arasında en bilinenlerinden ve de önem arz edenlerinden biri de M.Ö. VI. yüzyıl dolaylarında Karyanda'lı Skylaks tarafından gerçekleştirilmiş olandır. Skylaks, Pers kralı Dareios tarafından Indos'a (Hindistan'a) bir inceleme-araştırma gezisine yollanmış ve oradaki gözlemlerini tamamlayarak iki buçuk yıl sonra dönmüştür (Hdt. IV. 44). Kendisinin düzenlemiş olduğu bu keşif seferinin raporu da M.Ö. IV. yüzyılda, Pseudo-Skylaks olarak adlandırılan bir yazar tarafından kaleme alınmıştır. Bu raporda Afrika Kıtası'yla ilgili verilen bilgilendirmelerin büyük bir bölümü de (özellikle Skylaks periplus 112) Hannon'un keşif seferi sonucunda kayıt altına aldığı raporun içeriğini kapsamaktadır. Konuya ilişkin olarak ayrıca bk. Arslan 2012, 239.

49 Warmington 1940, 57; 1960, 62; Huß 1985, 77; 1990, 41; Hair 1987, 48; Kitchell 1998, 488; Irby-Massie Keyser 2002, 116; Lipiński 2004, 436; Davis 2009, 164; Ameling 2011, 44; Schoff 2014, 10.

50 Söz konusu yüzyıllarda Kartaca'nın politik ve ekonomik durumu hakkında ayrıca bk. Moscati 2004, 168-169; farklı tarihlendirme önerileri hakkında bk. ve krş. Mitchell 1850, 210; Bunbury 1879, 332; Warnecke 1999, 439; Roller 2006, 31 dn. 72; Riffenburgh 2012, 9.

51 Periplus'un gerçekleştirildiği dönemi kapsayan Kartaca sufes'lerinin listesi hakkında daha ayrıntılı bilgi için bk. Mullerus 1990, XXI.

52 Hdt. IV. 43; Sarton 1993, 299-300.

53 Herodotos'un söz konusu pasajlarında geçen bilgiler doğrultusunda yapılmış olan bir tarihleme önerisi hakkında bk. ve krş. Hennig 1927, 379. Hannon'un seferinin Sataspes'in seferinden daha erken bir zaman dilimine tarihlendirilemeyeceği hususunda ayrıca bk. Daebritz 1912, 2360. 
keşif ve kolonizasyon hareketi ${ }^{54}$ çeşitli doğal felaket-hadiseler ve de erzak sıkıntısı gibi engeller sebebiyle sonuçlanamamış, yolculuk yarıda kesilmek suretiyle başlangıç noktası olan Kartaca'ya geri dönüş yapılmıştır. Yolculuğun fırtınadan uzak ve tehlikesiz bir deniz yüzeyinde yapıldığı göz önüne alındığında (metin içerisinde de fırtınalı bir havaya veya çetin deniz şartlarına dair ibareler bulunmamaktadır), geminin hızlı bir şekilde seyrini sürdürebildiği söylenebilir ${ }^{55}$.Bu doğrultuda pentekontoros türü gemiler için saatlik maksimum hız sınırı olarak belirtilen 9,5 knot ${ }^{56}$ hıza zaman zaman ulaşmış olabileceği ve bu hızın yaklaşık 3 knot altındaki ortalama bir hızla da yolculuğun sürdürülebileceği ihtimal dâhilinde bir açıklama olarak görülebilir. Bu suretle seferi boyunca geminin maksimum hızına ulaştığı sürede 17,5; ortalama seyir hızı halindeyken de 12 $\mathrm{km} / \mathrm{h}^{\prime}$ lik bir mesafeyi geride bıraktığı hesaplanmaktadır.

Kartaca'ya dönüşün ardından Hannon liderliğindeki Kartacalılar yolculukları süresince kendi dillerinde yazdıkları seyir günlüklerini bir araya getirerek Kartaca Kenti'ndeki Fenike'de tapınımı bulunan ve aynı zamanda da Kartaca'nın baş tanrısı olan Ba'al Hammon'aa ${ }^{57}$ adakta bulunmak istemişlerdir ${ }^{58}$. Bu istek sonucunda da sefer günlüklerini ihtiva eden kayıtları adak ifadeleri içeren levhalar halinde yazıya geçirerek (mermer tabletler ya da daha büyük olasılıkla bronz levhalar biçiminde, Augustus'un Res Gestae ${ }^{59}$ veya Herakleitos'un kitabını Ephesos Artemis

Metinde verilen yolculuk sürelerinin toplamı gün hesabıyla 33,5 güne tekabül etmektedir, bu rakama metinde rakamsal olarak verilmeyen yolculuk süreleri de -azami olarak- eklenince, toplam yolculuk süresi 35 (ya da +5) güne ulaşmaktadır. Arrianos'un bu yolculuğun süresiyle ilgili vermiş olduğu bilgi için bk. Arr. Ind. XLIII. 11-14; yolculuk süresi hakkında farklı görüşler ve değerlendirmeler için ayrıca bk. Thomson 1948, 75.

55 Bir geminin yolculuk hızını belirleyecek unsurların başında iklim şartları, rüzgâr yönü-cinsi, deniz yüzeyindeki dalga ve akıntı şiddeti gibi çevresel ve de geminin şekli, mürettabatın yetkinliği ve gemide taşınan yükün miktarı gibi fiziksel faktörler bulunmaktaydı. Örneğin, yaz aylarında kuzeyden güneye doğru yolculuk yapan denizciler kuzey rüzgârlarından faydalanarak yolculuk sürelerini kısaltabilmekte ve hızlı bir şekilde yol alabilmekteydiler. Ya da bunun tam aksine, güney-kuzey istikametindeki seferlerde yolculuk süreleri uzayabilir ve seferin hızı düşebilirdi. Bu bağlamda Hannon'un yolculuk istikametinin de kuzey-güney doğrultusunda devam ettiği dikkate alınacak olduğunda, söz konusu kuzey rüzgârlarından faydalanmış ve yolculuk süresini kısaltmış olabileceği düşünülmektedir. Antikçağda deniz seferlerinin hızı ve yolculuk süreleri hakkında ayrıca bk. Meijer - van Nijf 1992. denizcilikte kullanılan hız birimidir.

57 Ba'al-Hammon, Hellen Pantheonu'nda Kronos (ya da Zeus), Latin Pantheonu'nda ise Saturnus ile özdeşleştirilmektedir. Aynı zamanda Fenikelilerin en önemli kentlerinden biri Ugarit'in de baş tanrısı olan Ba'al, Mesopotamya tanrıları arasında oldukça önemli bir yere sahip olmakla birlikte Fenike tanrısı El ile de ortak kökene sahiptir. Öyle ki Fenike pantheonunda El olarak isimlendirilen bu tanrının yerini daha sonra Ba'al "Efendi, hükümdar" tanrı alır. Söz konusu Ba'al (Haddu olarak da bilinir ve "gürleyen tanrı" olarak tapınım görür) Mezopotamya Dini'ndeki şimşek tanrısı Adad, Anadolu Theogoniası'nda Tessub, Mitanni Dini'nde Kumarbi ve M.Ö. I. binyıl Suriye'sine ait Pantheon'daki Hadad ile denktir. Ba'al hakkında detaylı bilgi için bk. Warmington 1981, 453-454; Lipiński 2004, 436; Wyatt 2007, 118; Gasparini 2015, 481. Kartaca tanrılarının Hellen ve Roma Pantheonu'ndaki karşııkları hakkında ayrıca bk. Lurker 1987, 28; Clifford 1990, 62.

Mund-Dopchie 2003, 49.

Roma'nın ilk imparatoru Augustus'un ölümünden yaklaşık bir yıl önce (M.S. 3 Nisan 13) üç rulo halinde düzenlediği vasiyetnamesine ait ikinci rulo kendisinin bireysel olarak gerçekleştirdiği başarılarının ve yaptığı faaliyetlerin bir listesidir. Res Gestae (Yapılan İşler) olarak isimlendirilen bu belge sunduğu bilgiler bakımından Hannon'un periplus'una benzer bir takım bilgiler içermektedir (özellikle Augustus tarafından kurulan kolonilerin sıralandığı R. Gest. div. Aug. XXVIII. ve periplus'un V. maddeleri birbirleriyle paralel 
Tapınağı'na adaması ${ }^{60}$ örneğindeki gibi) tapınak sunusunda bulunmuşlardır ${ }^{61}$. Bu tabletler/ levhalar daha sonradan, -muhtemelen- M.Ö. IV. yüzyılda özetlenerek Hellence'ye çevrilmişler ve bu suretteki halleriyle günümüze ulaşabilmişlerdir ${ }^{62}$.

Hannon öncülüğünde düzenlenen bu keşif seferinin -öncelikli olarak- askeri, siyasi ya da dini açılardan bir amacı bulunmamaktaydı ${ }^{63}$. Temel anlamda yeni pazar alanları arayışı odaklı ve bu

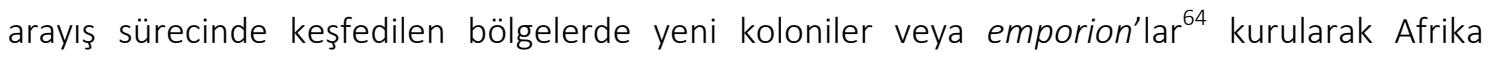
kıyılarındaki Kartaca hâkimiyetinin güçlendirilmesini hedefleyen ${ }^{65}$ ve de her şeyden önce sosyo-

bilgiler vermektedir). Öyle ki söz konusu vasiyetname ve Hannon'un keşif seferi raporu ulusal liderler tarafından yapılan-gerçekleştirilen işlerin genel bir dökümünü kapsamaları bakımından (kısmen de olsa) birbirleriyle kesişmektedir. Ayrıca Augustus Res Gestae'ın tunç levhalar halinde yazıya geçirilerek kendisine ait anıt mezar (Mausoleum Augusti) girişinin iki yanına da dikilmesini emretmiştir. Daha sonra da Res Gestae belgeleri kopyalanarak ve Hellence'ye çevrilerek Küçük Asya sınırları içerisindeki Apollonia, Ankyra, Pergamon ve Pisidia Antiochiası gibi kentlerdeki imparator tapınaklarında ( $\sum \varepsilon \beta \alpha \sigma \tau \varepsilon i ̃ o v=$ Sebasteion) muhafaza altına alınmış ve halkın okuması amacıyla da sergilenmiştir. Augustus'un vasiyeti hakkında G. Suetonius Tranquillus'un aktarımı hakkında bk. Suet. Aug. 101; Augustus'un söz konusu vasiyetinin Hellence bir kopyasını içeren Monumentum Ancyranum hakkında bilgi için ayrıca bk. Dürüşken 2009, 7-13. M.S. III. yüzyıl ortalarında yaşadığı düşünülen Diogenes Laertios'un bildirimine göre (IX. 6) Ephesos'lu Herakleitos eserini/kitabını, ancak uzmanlar okuyabilsin ve halkın kolayca küçümseyebileceği bir kitap olmaması amacıyla, bazı kişiler için de özellikle anlaşılmaz bir dilde yazarak, Artemis Tapınağı'na adadı. Diogenes Laertios'un bu bildirimi dikkate alınacak olduğunda, Hannon ve keşif seferine ait kayıtların da Kartaca'nın elit- ticari (okuma yazma bilen tüccar) zümresine hitaben baş tanrı Ba'al-Hammon Tapınağı'nda muhafaza altında tutulmuş ve böylelikle sıradan halkın metne (kutsal bilgiye) erişimi sınırlandırılmak istenmiş olabilir. Bu amaca ek olarak söz konusu belgelerin devletin resmi arşivi niteliğinde Ba'al-Hammon tapınağında dokunulmaz kılınarak her türlü tahribat ve müdahaleden uzak tutulması ve kutsal bir metin olarak algılanarak korunması da amaçlanmış olabilir. Herakleitos hakkında detaylı bilgi için ayrıca bk. Osborne 1997, 80-106; Russell 1945, 38-48.

Mommsen 1908, 152; Casson 19792, 63.

62 Wright 19514, 263; Tozer 1971, 104; Geus 1994, 98; Mund-Dopchie 2003, 49; Lipiński 2004, 436.

63 Lipiński 2004, 436.

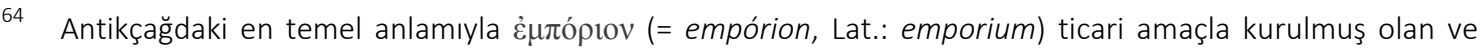
herşeyden önce mal (emtia) alım-satımı, değişimi, depolanması ya da nakledilmesi gibi amaçlara hizmet eden ekonomik yerleşimlere verilen terimsel adlandırmadır. Söz konusu yerleşimler genel olarak sahil kesimlerinde ya da gemi ulaşımının mümkün olduğu nehirlerin kıyılarında konumlandırılmakla birlikte kara ticaretinden çok deniz ticaretiyle uğraşan tüccar (emporos) kesimin yoğun olarak kullandığı alanlardı ve bu doğrultuda da liman-rıhtım yapılarına sahip olurlardı. Buna ek olarak emporion'lar kimi zaman bağımsız ve tekil yerleşimler olarak (en önem arz edenleri Pithekoussai, Al Mina, Tartessos, Neapolis ve Naukratis örneğindeki gibi) karşımıza çıkarken kimi zaman da Atina, Korinthos ve Byzantion gibi ticaret hacmi yüksek kentlerin teritoryumlarındaki pazar alanları olarak anılmaktaydılar. Bazı durumlardaysa (örn: Mısır'da Nil Nehri deltasında kurulmuş olan İskenderiye kenti) emporion olarak kurulan yerleşim alanları zaman içerisinde gelişerek ve genişleyerek polis statüsüne sahip yerleşim alanlarına dönüşebilmekteydiler. Bu doğrultuda bir kentin ya da yerleşim biriminin emporion olarak adlandırılabilmesi için en önemli ekonomik kaynaklarının tarım, hayvancılık ve ormancılıktan ziyade ithalat ve ihracat faaliyetlerine odaklanması gerekiyordu. Ayrıca söz konusu alanlarda ikamet eden vatandaş topluluğunun büyük çoğunluğu da ticari faaliyetler kapsamında işveren, iş̧̧i, ara eleman (taşeron), nakliyeci, komisyoncu veya tefeci gibi meslek guruplarına mensup ticari bir zümre kimliğine sahip olmakla birlikte kentin vergi gelirlerinin büyük çoğunluğu da ulusal-uluslararası ticaretten kazanılan vergi gelirlerine dayanmaktaydı. Bütün bu özelliklerine ek olarak Emporion yerleşimleri çok uluslu bir sosyal yapıya sahip olmasından dolayı farklı tanrılara ait mabetlere, hukuki geleneklere ve toplumsal ritüellere de sahip olabilmekteydi. Emporion hakkında ayrıntılı bilgi için bk. Hansen 1997, 83-100; Demetriou 2012, 24-63.

Öngör 1954, 5; Bevan 1859, 8; Forbiger 1877, 66. 
ticari perspektifli bir bakış açısıyla düzenlenmiş ticari-coğrafi bir seyahatti. Hannon bu sefer

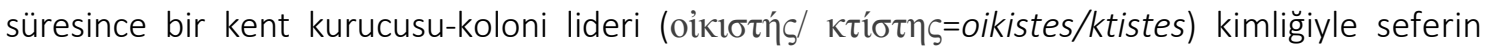
yöneticiliğin yürütmekteydi. Sefere katılanların sosyal statüleri de büyük çoğunlukta siyasi-politik kaygılardan uzak sivil bir yapıya sahipti, zira metin içerisinde de askeri (örn: saldırı ya da savunma amaçlı askeri organizasyonlara dâhil), siyasi (örn: anlaşma ya da diplomatik görüşme odaklı elçilik görevleriyle gemide bulunan) ya da dini (örn: kehanet taşıyan ya da bir bayram kutlaması-kutsal yarışlara izleyici [theoriai] olarak giden ya da kamusal-özel dini misyonlarla görevli rahipler) amaçlarla yolculuğa katılmış seyahlara/gezginlere ilişkin herhangi bir terminolojik kullanım bulunmamaktadır. Seferin düzenleniş amacı aynı zamanda da ticari genişleme ve iktisadi açılım (ekspansiyon) odaklıydı ve bu doğrultuda keşfedilen yerlere yeni koloni kentler kurulması ve bu kentler vasıtasıyla da Kartaca'nın dış ticaret hacminin-hareketliliğinin canlandırılması hedeflenmekteydi ${ }^{66}$.

Sefere katılanlar toplamda yak. 30.000 kişiye ulaşan erkek ve kadın Kartaca yurttaşıydı ve bu kişiler kurulacak olan yeni koloni kentlere yerleştirilmek ve böylelikle de söz konusu kentlerdeki iş gücü potansiyelini sağlamak amacıyla gemilere bindirilmiş olmalıydılar ${ }^{67}$. Sefere katılan toplam gemi sayısı ise altmış adet pentekontoros olarak verilmektedir ${ }^{68}$. Metin içerisinde verilen gemi ve yolcu rakamları orantısal olarak (30.000 yolcu/60 pentekontoros) birbirine bölündüğündeyse gemi başına düşen yolcu sayısı kürek çeken 50 kişi de dâhil olmak üzere, 500 kişi olarak hesaplanmaktadır. Ancak bu rakam tamamıyla abartılı bir aktarım olarak gözükmektedir, zira antikçağda bir pentekontoros'un yaklaşık olarak 500 kişilik bir yolcu taşıma kapasitesine sahip olması ve buna ek olarak da beş yüz kişinin erzağını taşıyabilmesi oldukça zorlama bir kabulü beraberinde getirmektedir. Diğer bir ihtimal ise, metinin Kartaca Dili'nden Hellence'ye çevrilmesi sırasında yapılan bir transkripsiyon ya da tercüme hatası neticesinde söz konusu rakamın yanlış verilmiş olmasıdır. Söz konusu bu sebeplerden ötürü belirtilen rakamı daha düşük bir miktara indirgemek ve paralelinde keşif seferine dâhil olan toplam yolcu nüfusunu bu görüş doğrultusunda yorumlamak gerekmektedir ${ }^{69}$. Buna ek olarak söz konusu gemiler savaş gemilerinden ziyade yük ve ticari taşamıcalıkta kullanılan nakliye gemileriydiler ve nehirlerin içerisinde dahi

67

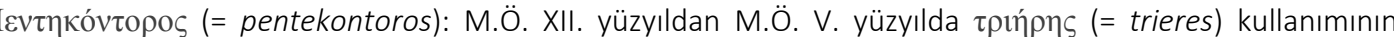
yaygınlaşmasına kadar, özellikle Hellen ve Kartaca donanmaları tarafından sıkıkla kullanım görmüş olan elli kürekli savaş gemisidir. Bu gemilerinin sağ ve sol omurgalarında yirmi beşer kürekçi bulunmaktaydı ve toplamda elli kürekçinin gücüyle hareket ettirilmekteydiler, uzunlukları ise yaklaşık olarak 38 metreydi ve

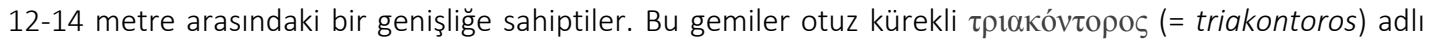
gemilerin geliştirilmesi ve hacminin büyütülmesi sonucunda inşa edilmiştir. Pentekontoros'ların kullanıma girmesiyle birlikte bir geminin seyri için uygun rüzgârların beklenmesine gerek kalmamış, buna ek bir avantaj olarak da kürek çeken mürettebatın arttırılmasıyla ters akıntılara karşı koyabilecek hıza ulaşıııışır. M.Ö. XII. yüzyıl ve öncesinde Pentekontoros'un kullanımı hakkında bk. Hom. II. II. 718-720; XVI. 168-170; Od. VIII. 34-36; 48; XIII. 20-22. Alalia Savaşı'nda Phokailılar tarafından Etrüsklere ve Kartacalılara karşı kullanım görmüş olması hakkında ayrıca bk. Hdt. I. 166. Pentekontoros hakkında daha detaylı bilgi için ayrica bk. Torr 1895, 21-22; Haas 1985, 35; Morrison - Coates 1987², 246; Starr 2000, 18-19; Casson 2002, 55-56; Gould 2011², 68.

69 Örnek olarak Demerliac - Meirat 1983, 64-67; Hannon'un keşif seferi üzerine yaptığı çalışmada sefere iştirak eden yolcu sayısını abartıı bulmakta ve otuz bin yerine beş bin yolcu sayısını önermektedir. Daebritz de $(1912,2360)$ yolcu rakamlarındaki abartının tercüme esnasında bir sıfııın fazla yazılmış olabileceğinden kaynaklandığını belirterek sayının üç bin olarak algılanması gerektiğini belirtmektedir. 
seyredebilecek yapıya (ince ve uzun gövdeli) sahip olmalıydılar. Zira söz konusu gemilerin savaş gemisi olarak yorumlanabilmesi için askeri herhangi bir terim bulunmadığı gibi, kadınların ve erzak maddelerinin de gemiye yüklenmiş olması bu gemilerin savaş gemisinden ziyade nakliye amacıyla kullanım gören gemiler olabileceği önerisini desteklemektedir ${ }^{70}$.

Antikçağda ilerleyen yüzyıllarla birlikte Hannon'un söz konusu keşif seferi hakkında direk bilgi vermeye devam eden Pomponius Mela ${ }^{71}$ gibi coğrafya yazarları dışında ${ }^{72}$, Gaius lulius Solinus $^{73}$ gibi dolaylı yoldan bilgi veren yazarlar da mevcuttur. Solinus eserinde M.Ö. II. yüzyılda yaşadığı düşünülen ve coğrafya konusunda çalışmaları bulunan ancak kitap/kitapları günümüze ulaşamamış olan Lampsakos'lu Ksenophon'un aktarımıyla Hannon ve keşif seferi hakkında bilgilendirmelerde bulunur ${ }^{74}$.

Solinus'un söz konusu anekdotuyla birlikte Hannon'un keşif seferi hakkındaki tarihsel aktarımlar yaklaşık on üç yüzyıl sürecek olan derin bir sessizlik süreci içine girmiştir. Bu uzun süreli bilgi yoksunluğu Rönesans Dönemi'yle birlikte son bulmuştur. Bu dönemle birlikte, yak. 1520'li yıllarda, Hannon ve keşif seferi hakkındaki çalışmalar öncelikli olarak dolaylı araştırmalar vasıtasıyla başlamıştır ${ }^{75}$. Söz konusu bu çalışmalar Pomponius Mela ve Gaius Iulius Solinus'un eserlerinin edisyon-kritik ve tercüme çalışmalarını kapsayan, bu bağlamda Hannon ve de Periplus'una da kısaca değinen ve yüzeysel seviyedeki araştırmalardan daha da ileriye gidemeyen bir niteliğe sahiptir ${ }^{76}$. Ilerleyen yüzyıllarla birlikte araştırmalar hız kazanmıştır ve konu hakkında bir mihenk taşı niteliğindeki ilk çalışma 1533 yılında Basel'de, Çek asıllı ünlü bilim adamı Sigismundus Gelenius tarafından gerçekleştirilmiştir ${ }^{77}$. Kendisi Periplus of the Erythraean Sea = Erythre Denizi'nin (Kızıl Deniz) Keşif Seferi başlıklı edisyon-çeviri çalışmasının sonuna appendix (ek) olarak Hannon'un periplus'unu da dâhil etmiştir ${ }^{78}$. Bu çalışmasının içeriğini sağlayan metne de Heidelberg Üniversitesi Kütüphanesi vasıtasıyla Basel'de ulaştığı Codex Palatinus Graecus 398 (bk. Fig. 2) olarak isimlendirilen el yazması vasıtasıyla ulaşmıştır ${ }^{79}$. Gelenius'un bu eserini yayınlamasının üzerinden henüz çok da zaman geçmemişken, 1550 yılında, Hannon ve periplus'u İtalyan filolog Giambattista Ramusio tarafından (Gelenius'un metni temel alınarak) Italyanca'ya çevrilip yorumlanmış ve Venedik'te de yayınlanmıştı ${ }^{80}$. Ramusio'nun söz konusu eseri kendisinin Afrika kıyıları boyunca yapmış olduğu seyahatleri içeren bir rapordur ve Orbis = Ülkelerin Tasvirleri ya da Dünyanın Konumu Üzerine isimli eseriyle tanınan Mela, coğrafya üzerine Latince bir eser kaleme alan en erken Latin yazarıdır. Hakkında daha ayrıntıı bilgi için ayrıca bk. Howatson 2013, 767.

Lipiński 2004, 444

Mela. III. 90.

Latin yazarı, büyük olasılıkla M.S. 200 civarında Collectanea Rerum Memorabilium - Anılmaya Değer Şeylerin Derlemesi adlı yapıtını yazdı. Kendisi bazen Polyhistor cognomen'iyle de anılır. Mediterranum Maris, günümüzdeki Akdeniz için kullanılan Latince terimin yaratıcısı da kendisidir. Hakkında daha ayrıntılı bilgi için ayrıca bk. Howatson 2013, 872-873.

Solin. LVII.

Mund-Dopchie 2003, 50.

Bahsi geçen çalışmalar ve künyeleri hakkında bk. Mund-Dopchie 2003, 50 dn. 8.

Gelenius 1533; Watkins 1800, 603; Mund-Dopchie 1994, 111.

Schoff 2014, 7.

Lipiński 2004, 435.

Ramusio 1550, 121-124. 
Hannon'un Periplus'u da kendi seyahatiyle bağlantılı bir örgü içerisinde çalışmasına dâhil edilmiştir. Metnin italyanca'ya çevrilmesinin altı yıl sonrasında, 1556 yılında, Hannon ve periplus'u Fransız dilbilimci Jean Temporal tarafından Fransızca tercümesiyle birlikte yayınlanmıştır ${ }^{81}$.

17. yüzyıldaki ilk çalışma ise Ingiliz filolog Samuel Purchas tarafından gerçekleştirilmiştir. Kendisi 1625 yılında metni (yorumuyla birlikte) İngilizce'ye çevirerek yayınlamıştır ${ }^{82}$. Yeniçağın ünlü bilim insanlarından biri olan Isaac Vossius ise 17. yüzyıldaki çalışmalar açısından oldukça önemli diğer bir isimdir ${ }^{83}$. Vossius, Observationes ad Pomponium Melam de Situ Orbis= Pomponius Mela'nın Dünyanın Konumu İsimli Eserine Yönelik Gözlemler başlıklı çalışmasında Mela'nın Hannon hakkında vermiş olduğu anekdotlardan yola çıkarak Hannon ve Periplus'u hakkında önemli birtakım gözlem ve değerlendirmelerde bulunmuştur ${ }^{84}$. Abrahamus Berkelius da 1674 yılında bir sonraki çalışmanın altına imza atan araştırmacı olmuştur. Kendisi Stephanus Byzantinus'un edisyonunu yaptığı çalışmasında Hannon ve periplus'unun Hellence-Latince çevirisini kullanmıştır ${ }^{85}$. Onun eserinde kullanmış olduğu bu çeviri İsviçre'li bibliyografi yazarı ve aynı zamanda da bir doğa tarihçisi olan Conradus Gesnerus tarafından tercüme edilen ve onun kuzeni Andreas Gesnerus tarafından da yorumlanarak 1559 yılında Zürih'te yayınlanan Latince edisyon ile aynıdır ${ }^{86}$. Hannon ve periplus'unu konu edinen 17. yüzyıldaki son edisyon çalışmasıysa 1698 yılında John Hudson tarafından gerçekleştirilmiştir. Hudson'un Oxford'ta yayınlamış olduğu Geographiae Veteris Scriptores Graeci Minores =Tarihi Coğrafyanın Gözardı Edilmiş (Arka Planda Kalmış) Grek Yazarları başlıklı eseri kapsamında periplus'un Hellence-Latince edisyonu da yayınlanmıştır ${ }^{87}$. 18. yüzyılla birlikteyse Hannon'un keşif seferini konu alan çalışmalar giderek hız kazanmış ve bu yolculuk üzerine birçok bilim adamı tarafından çeşitli tezler öne sürülmüştür. Sonuç olarak, toplamda 650 kelimeden daha da uzun bir kayda sahip olmayan bu yolculuk raporu, yüzyıllar boyunca binlerce yorum, açıklama ve de bilimsel tartışma neticesinde kaleme alınan yüzlerce makale ve bir düzineyi aşkın monografik eseri de beraberinde getirmiştir ${ }^{88}$.

Gelenius vasıtasıyla tarihsel kayıtlarda yeniden anılmaya ve bilimsel çalışmalara konu olmaya başlayan Hannon ve periplus'unu içeren metinler antikçağdan ortaçağa kadar varlığına dair izleri sürdürebilmiş ve akabinde de klasik filologlar ve modern coğrafya-tarih araştırmacıları tarafından belirli aralıklarla kopyalanmak suretiyle (Hellence-Latince edisyonları temel alınarak) günümüze ulaşabilmiştir. Papirüslere kaydedilmiş el yazmaları formunda keşfedilen bu periplus belgelerinin tarihsel süreçte geçirdiği yolculuksa tam olarak bilinememekle birlikte hakkında çeşitli görüş ve yorumlar ileri sürülebilmektedir. Söz konusu bu yorum ve görüşler ışı̆̆ında, periplus belgeleri öncelikle Kartaca tapınak arşivlerinden Roma İmparatorluğu kütüphanelerine ve oradan da (Batı Roma'nın yıkılmasıyla birlikte) Doğu Roma Imparatorluğu kütüphanelerine nakledilmiştir. Daha sonra ise Doğu Roma Imparatorluğu'nun köklü arşivlerine sahip kentlerin

81 Temporal 1556.

82 Purchas 1625

83 1618-1689 yılları arasında yaşamış olan Hollanda asıllı ünlü bir klasik filolog ve de coğrafya bilimcisi. Kendisi antik kaynaklarda geçen coğrafi metinler üzerine yorum ve analiz çalışmalarında bulunmuş ve söz konusu çalışmalarıyla ün kazanmıştır. Vossius hakkında daha detaylı bilgi için bk. Seccombe 1900, 392-396.

84 Vossius 1658, 302.

85 Berkelius 1674, 66-98.

86 Mund-Dopchie 2003, 51.

87 Hudson 1698, 1-6.

88 Casson $1979^{2}, 83$. 
birinden -muhtemelen Konstantinopolis'ten- 1453 yılında imparatorluğun yıkıış̧ının hemen ardından, XV. yüzyıl Kardinalleri tarafından Batı Avrupa kütüphanelerine götürülmüştür ${ }^{89}$. Böylelikle Avrupa kütüphaneleri aracılığıyla Ortaçağ bilim merkezlerine ve tapınak arşivlerine ulaştırılabilen periplus belgeleri açısından en önemli iki el yazması da metnin çevirisi ve de yorumlanması açısından günümüze değin kaynak olarak kullanılagelmiştir. Bunlardan ilki ve en bilineni Codex Palatinus Graecus başlı̆ıyla Universitätsbibliothek Heidelberg arşivinde 398 numaralı kayda sahip olan el yazmasıdır ve M.S. IX. yüzyılın sonlarına tarihlendirilmektedir ${ }^{90}$. İkinci ve diğer bir el yazması da Codex Palatinus Graecus'un XIV. yüzyılda oluşturulmuş olan kopyasıdır $^{91}$. Bu kopyanın nüshaları da Avrupa'daki farklı kütüphanelerde ve de manastır arşivlerinde bulunmaktadır. Bu nüshaların en önemlisi ve diğer iki kopyasının içerik olarak temel alındığı forma sahip olan el yazması Yunanistan'da bulunan Athos Dağı'ndaki Vatopedi Manastırı Arşivi'nde (655 arşiv kayıt numarası ile) korunmaktadır. Diğer ikisi de Londra'daki British Library'de (19391 arşiv kayıt numarası ile) ve Paris'teki Bibliothèque Nationale de France'da (suppl. grec. 443A arşiv kayıt numarası ile) muhafaza altına alınmıştır. Ancak söz konusu bu XIV. yüzyıl kopyası Hannon ve periplus'una ait edisyon-çeviri çalışmalarında X. yüzyıla ait el yazmasına nazaran daha az tercih edilmiş ve kullanım görmüştür. Yapılan edisyon-kritik çalışmaları genellikle Heidelberg Üniversitesi Kütüphanesi arşivindeki (günümüzde de dijital ortama da aktarılmış olan) el yazmasından okunarak gerçekleştirilmiştir.

Sonuç olarak antikçağdan günümüze kadar oldukça uzun ve de dolaylı yollardan ulaşabilmiş bu seyir kaydı güvenilirliği ve içerisindeki bilgilerin geçerliliği bakımından oldukça detaylı ve kapsayıcı tartışmaları beraberinde getirmiştir ${ }^{92}$. Bu tartışmalar yaklaşık 2500 yıl boyunca metnin geçirmiş olduğu tercüme aşamaları ve kopyalanma süreçleri göz önüne alınacak olduğunda, anlayışla karşılanabilir bir güven eksikliğini de beraberinde getirmektedir ${ }^{93}$. Ancak bu çelişkiler ve de hatalar metnin aynı bölgeyle ilgili ve yaklaşık aynı zaman dilimlerinde eserler kaleme almış olan antikçağ yazarlarının konuyla ilgili (birincil önem taşıyan) görüşlerine başvurularak büyük ölçüde giderilmiştir ve metin hakkındaki bu güven eksikliği asgari seviyeye indirgenmiştir. Buna ek olarak Rönesans'tan günümüze Hannon ve keşif seferi tutanakları hakkında yapılan edisyonkritik çalışmaları neticesinde de metinde hatalı ya da konu dışı bulunan kısımlar metinden

Hair 1987, 44; Mund-Dopchie 2003, 49 dn. 2.

Blomqvist 1979, 57; Bianchetti 1999, 420.

Söz konusu bu nüshanın yalnızca bir bölümü Hannon ve periplus'una yönelik oluşturulmuş olan kayıtları içermektedir. El yazmasının içeriği hakkında detaylı bilgi için ayrıca bk. Gutschmidt 1891, 232-237.

Hannon ve Periplus'unun içeriğindeki verilerin geçerliliği ve doğruluğu konusundaki tartışma ve görüşler hakkında bk. Blomqvist 1979, 8-14.

93 Kartaca'nın yönetim biçimi, kent kurumları, dini, edebi yazın geleneği ve sosyo-kültürel yapısı hakkındaki bilgilerimiz genel olarak Hellen ve Latin yazarlarının eserlerinde sunulmuş olan verilerden kaynaklanmaktadır. Ancak göz ardı edilmemesi gereken ve oldukça önemli bir hususu belirten nokta şudur ki, Latin ve Hellen yazarları Kartaca gibi köklü bir medeniyet hakkında detaylı ve geneli kapsayıcı bilgilere sahip değillerdi. Buna ek olarak, kendi dönemlerinin siyasi konjonktürleri içinde taraflı bir bakış açısıyla eserlerini yazmış olmaları da dikkate değer diğer bir varsayımdır. Bundan dolayı Hellen ve Latin kaynaklarında Kartaca ve hinterlandındaki Afrika toprakları hakkında bilgi aktarımı yapııırken bazı kasıtıkasıtsız hatalar yapılmış olabilir. Ayrıca, antikçağ boyunca Kartaca tarihi hakkında bilgi verilmesi söz konusu olduğunda da genel eğilim birincil olarak (Kartaca Dili'nde yazılmış olan kaynakların azlığı ya da mevcut olanların okunup anlaşılaması sebebiyle) Hellen ve Latin yazarlarının kullanılması üzerineydi. Kaynak analizi hakkında ayrıca bk. Salama 1981, 513; Steinby 2014, 5. 
çıkartılmış ve eksik kısımlar da diğer el yazmalarıyla mukayese edilerek tamamlanmıştır ${ }^{94}$. Söz konusu bütün bu çalışmalar neticesinde de günümüz coğrafi keşifler tarihine ışık tutan ve aynı zamanda da antikçağda edebi bir yazım tarzı haline gelen periplus yazım geleneği konusunda oldukça önemli niteliğe sahip bir seyrüsefer arşivi günümüz bilim dünyasının ve konuyla ilgili çalışmalar yürüten bütün araştırmacıların kullanımına kazandırıımışıı. Hannon ve periplus'u bu yönüyle disiplinlerarası çalışmalar açısından da oldukça önemli bir belge niteliğine sahiptir ${ }^{95}$. Söz konusu bütün bu özellikleriyle Hannon ve periplus'u Kartaca ve onun Batı Akdeniz ekspansiyonunu ele alıyor olmasıyla mikro-bölgesel bir etkiye sahiptir. Diğer taraftan Afrika Kıtası'nın Atlas Okyanusu boyunca uzanan kuzey-batı sahilleri hattında sıralanan tarihteki ve günümüzdeki birçok ülkenin tarihine, coğrafyasına, etnolojisine, flora-fauna yapısına ve kültürüne ışık tutması nedeniyle de makro-bölgesel bir çalışma alanını mercek altına almaktadır. Bunlara ek olarak Hannon ve keşif seferi, denizcilik tarihi açısından ileride yapılacak yeni çalışmalara farkı bir bakış açısı kazandırmakta ve denizcilikte başarı göstermiş ulus-devletlerin başarılarının yalnızca ticari, askeri ve siyasi alanlarla sınırlanmadığını, denizcilik perspektifinde edebi alanlarda da önemli çalışmalar gerçekleştirdiklerini göstermektedir ${ }^{96}$.

1533 yılında Gelenius tarafından başlatılan ilk metin analizi çalışmalarından yalnızca 1950'li yılların ortalarına kadar Hannon'un periplus metnine ilişkin yüzü aşkın edisyon-kritik ve çeviri-yorum çalışması gerçekleştirilmiştir. Metin üzerindeki söz konusu bu çalışmalara ilişkin bibliyografya derlemesi hakkında bk. Diller 1952, 48-101.

95 Periplus hakkındaki çalışmalar ve araştırmalar yalnızca coğrafya-edebiyat tarihi gibi konuyla çok yakından ilgili temel çalışma disiplinlerinin dışında etnoloji, astronomi, botanik ve zooloji gibi farklı bilimsel disiplinleri de bünyesinde bir araya getirmiştir. Bu açıklamaya zooloji alanından örnek vermek mümkündür. Zooloji tarihi inceleme altına alındığında, 1847 yılında Amerikan doğa bilimcisi Thomas S. Savage periplus'un çevirisini okuduktan sonra Batı Afrika'da keşfetmiş olduğu yeni bir antropoit (insansı-insana benzeyen hayvan, genelde maymun familyasını tanımlamak için kullanılan bir üst cins tanımlamasıdır) türünü isimlendirmek için periplus'un on sekizinci paragrafında geçen gorilla terimini kullanmışıı. Kendisi tarafından ilk defa kullanılan bu terim de Zooloji terminolojisindeki karşılı̆ıına Hannon'un periplus'u vasıtasıyla kavuşmuş ve insana oldukça benzeyen, oldukça tüylü ve vahşi bir hayvan türü olan Goril bu terimle anılır olmuștur. Konu hakkında ayrıca bk. Savage 1847, 417-426; Blomqvist 1979, 5 dn. 2. Gorilla olarak tanımlanan hayvanların bölgede sıklıkla yaşadığı bilinen Şempanze ya da Babun olabileceği konusundaki tartışma hakkında ayrıca bk. Cavendish 2005, 330.

96 A. T. Mahan da denizciliğin tarihsel gelişimi ve deniz gücünün tarih üzerine etkisi hususunda bilgi verdiği eserinde benzer bir değerlendirmede bulunmaktadır. Mahan'a $(2011,31)$ göre; “deniz gücünün tarihi hiçbir şekilde sadece ülkeler arasındaki çekişmelerin, rekabetlerin, savaşta doruğuna çıkan şiddetin anlatılması değildir. Deniz ticaretinin ülkelerin zenginliği ve kuvveti üzerine olan büyük etkisi, onun büyümesini ve başarııını etkileyen doğru prensiplerin belirlenmesinden çok daha önce fark edilmişti". Mahan'ın deniz gücünün ana unsurları hakkındaki açıklamaları için ayrıca bk. Mahan 2013, 37-62. 
Kartacalıların Kralı ${ }^{97}$ Hannon' un ${ }^{98}$

\title{
Herakles Sütunları’nın Ötesindeki Libya Topraklarının Bölümlerine İlişkin Keşif Seferi Raporu
}

\author{
... ve de (Hannon) buralar keşfedildikten sonra bu keşif seferi raporunu \\ Kronos Tapınağı'nda adak olarak sundu.
}

I. Kartacalılar Hannon'un Herakles Sütunları'nın ötesine yelken açmasına ve de Libya-Fenike kentlerini ${ }^{100}$ kurmasına karar verdiler. Hannon da altmış adet pentekontoros'u (elli kürekli gemi) yaklaşık olarak otuz bin erkek ve kadınla doldurarak ve de gerekli olan erzakla birlikte diğer ihtiyaçları da temin ederek denize açıldı.

II. Böylece denize açıldıktan sonra Herakles Sütunları'nıı1 ${ }^{101}$ arkamızda bırakarak iki günlük bir zaman dilimi daha denizde yol almamızın ardından ilk kenti kurduk,

97 Burada kral olarak kullanılan $\beta \alpha \sigma ı \lambda \varepsilon v ́ c$ kelimesi, metnin Kartaca Dili'nden Hellence'ye çevrildiği göz önüne alındığında, kral anlamından çok Kartaca yönetim mekanizmasının başında bulunan Sufes olarak algılanmalıdır. Bu nedenden dolayı "Kartacaların Kralı Hannon" yerine "Kartacaların Sufes'i Hannon" daha uygun bir çeviri olacaktır. Ancak burada metnin Hellence aslına sadık kalınarak kral çevirisi kullanılmaktadır. Sufes hakkında ayrıca bk. dn. 43. Plinius ise Hannon'u kendi eserinde (nat. VI. 200) “... Hanno Poenorum imperator = Kartacalıların (Pönler) Imparatoru Hanno" olarak zikretmektedir. Söz konusu bu tanımlama Romalıların Imparatorluk Dönemi'nde Kartacalılar ve yönetim mekanizmaları hakkındaki bilgilerinin -

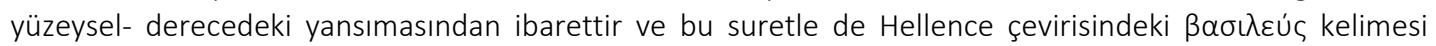
Latince'ye aktarılarak imparator olarak verilmiştir.

Hannon (Hel: "Avvwv; Lat: Hanno) Kartacalılar tarafından sıklıkla kullanılan bir isimdir (bk. Hoyos 2010, 245) ve Kartaca tarihsel kayıtlarında Hannon isimli birçok generale, amirale ve de Kartaca tarihine yön veren siyasi kişiliklere ait aktarımlar bulunmaktadır. Öyle ki M.Ö. 254-184 yılları arasında yaşamış olan Romalı ünlü komedya yazarı Titus Maccius Plautus'un Poenulus (Küçük Kartacalı) isimli eserinde de Kartacalı başkahramanın ismi Hanno olarak verilmektedir (bk. Plaut. Poen. I-X). Buna ek olarak, Roma ve Hellen isim kurmalarından farklı olarak Kartacalılar yalnızca bir isme sahip olurlardı ve onların bu isimleri genellikle Kartaca ve Fenike Pantheon'undan seçilmiş Baal, Astarte, Melqart gibi baş tanrı ve tanrıçaların isimlerine benzer (theophorik) isimlerdi. Ancak Kartacalıların isimlerine yönelik aktarımlar da -tıpkı her konuda olduğu gibi- Hellen ve Roma kökenli yazarların eserlerinden kaynaklandı̆̆ı için bu isimler yazarların kendi dillerine uyarladıkları yazıışları ya da kısaltmaları şeklinde günümüze ulaşabilmiştir. Örneğin tarihsel kayıtlarda Hamilcar olarak anılan ismin Kartaca Dili'ndeki karşılığı Habdmilqart/Abdmilqart'tır ve bu isim "Melkart'ın Hizmetine Adanmış" anlamına gelmektedir. Aynı şekilde Bomilcar da Bodmilqart olarak "Melkart'ın Emrindeki" anlamını vermektedir. Diğer bir örnek olarak Himilco ise Himilqart formuyla "Melkart'ın kardeşi" anlamını vermektedir. Hanno ise Hanniba[a]ı (Baal beni esirgesin), Zakarba[a]ı (Baal beni hatırlasın), Maharba[a]ı (Baal! Yetiş!) isimleri örneğinde olduğu gibi Hannonba[a]l olarak isimlendirilmekte ve bu formuyla "Onu [Baal'i] onurlandır!" anlamını karşılıyor olmaldır. Konu hakkında ayrıca bk. Hoyos 2010, 23-24.

99 Kronos tapınağı olarak belirtilen alan Kartaca kentinin baş tanrısı Ba'al Hammon'un tapınağı olarak algılanmalıdır. Konu hakkında ayrıca bk. dn. 57.

100 Libya antikçağda Hellenlerin Afrika kıtasını belirtmek istedikleri zaman kullandıkları coğrafi bir tanımlamadır ve bu suretle metnin Kartaca Dili'nden Hellence'ye çevirisi sırasında Kartacalıların Afika kıtası kıyılarında kurdukları kentler $\Lambda$ ıv

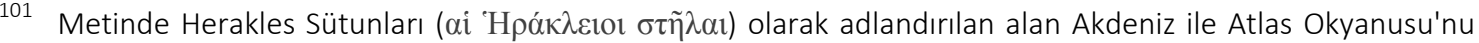
birbirine bağlayan, Avrupa ile Afrika kıtalarını da ayıran ve günümüzde de Cebelitarık Boğazı olarak adlandırılan kıstaktır. Metin içerisinde Kartaca'dan Herakles Sütunları'na kadar olan yolculuk ve ilerleyiş süreci hakkında herhangi bir bilgi verilmeden direk Herakles Sütunları'nın geride bırakılmasından sonraki sürece odaklanılmasının asıl sebebi söz konusu coğrafyanın Kartacalılar için tamamıyla bilindik bir coğrafya olmasından kaynaklanıyor olmalıdır. Bu doğrultuda Kartaca'dan denize açılarak Herakles Sütunları'na 
bu kenti de Thymiaterion ${ }^{102}$ olarak adlandırdık. Kentin aşağındaysa geniş bir ova uzanıyordu.

III. Daha sonra batıya doğru yelken açarak, ağaçlarla kaplı sarp bir Libya burnu olan Soloi' ${ }^{103}$ ulaştık.

IV. Burada Poseidon'un bir tapınağını inşa etmemizin ardından ${ }^{104}$, denizden çok da uzak olmayan, yoğun ve uzun sazlıklarla kaplı bir lagüne varıncaya kadar doğu istikameti yönünde yarım gün boyunca keşif seferini sürdürdük. Filler ve de burada otlanmakta olan çeşitli cinsten pek çok vahşi hayvan bu lagünün başında toplanmıştı.

V. Hemen hemen bir gün süren bir deniz yolculuğu yaparak lagünü geride bıraktıktan sonra deniz kıyısındaki Karikon Teikhos kentini, ayrıca da Gytte, Akra, Melitta ve Arambys olarak adlandırılan kentleri kurduk.

ulaşılmasına kadarki süreçte kayda değer herhangi bir bilgiye ya da yeni bir veri olarak nitelendirilebilecek bir bulguya ulaşılamamış bu suretle de bu süreç kayıt dışı bırakılmış olabilir.

102 Metin içerisinde anılan ve kolonileştirilen ya da yeniden kurulan kentlerin (söz konusu yerleşim birimlerinin kent statüsüne sahip olup olamayacağı tartışmaya açık bir konudur, bu sebeple bu yerleşimleri kent kimliğinden daha küçük ölçekte tasarlanmış ve öncelikli olarak ticari amaçla kurulmuş emporion'lar olarak algılamak daha uygun olacaktır) toplam sayısı yedidir. Mullerus'un edisyonu ve yorumu temel alınacak

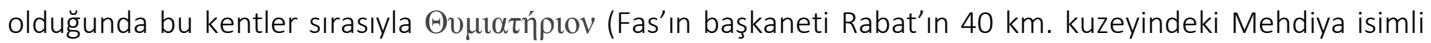

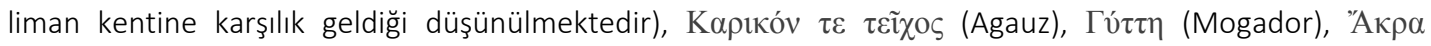

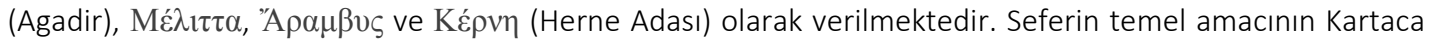
için yeni ticaret sahaları ve pazar alanları keşfedilmesi-oluşturulması olduğu dikkate alındığında, sefere katılanlardan belirli oranlardaki kadın ve erkek nüfusun yeni kurulan bu kentlerde iskân ettirilmiş olabileceği düşünülmektedir. Kartaca tarafından Libya kıyılarında kurulan koloni kentlerinin öncelikli amaçlarının ticaret ve mal nakliyesi olduğu hususundaki görüş hakkında bk. ve krş. Eichel - Todd 1976, 238. Buna ek olarak yeni kurulan kentlerin birbirleri arasında synoikismos yapmış olabilecekleri de uzak bir ihtimal olarak görülmemektedir. Metinde geçen kentlerin günümüzdeki coğrafi karşılıkları Rönesans Dönemi'nden itibaren kentlerin lokalizasyonu konusunda kapsamlı çalışmalar yürütülmüş olmasına rağmen net bir biçimde saptanamamakla birlikte yalnızca kentlerin mevcut iskân alanları hususunda birtakım öneriler ileri sürülmüştür. Ancak fikir birliği içinde kalınan tek kanı Kerne Adası'nda kurulan kent haricindeki bütün kentlerin günümüzdeki Fas sahilleri üzerinde kurulmuş olmalarıdır. Kentlerin lokalizasyonlarının değerlendirilmesi konusundaki tartışma ve görüşler için ayrıca bk. Bell 1836, 413; Mund-Dopchie 1994, 115-116; Culican 20035 , 543-546; Schoff 2014, 5-6.

103 Metinde Soloi olarak adlandırılan burun günümüzdeki Fas sahilleri üzerinde bulunan Spartel Burnu (Kaplan 2012, 25) ya da (birçok araştırmacı tarafından da kabul gören, örn. Schoff 2014, 7 et al.) daha güneyindeki Cantin (Meddouza) Burnu ile özdeşleştirilmektedir.

Hellen ve Romalı yazarlar genellikle Kartaca Dini ile ilgili aktarımlarda bulunurlarken Kartaca Tanrı ve Tanrıça'larına ait isimleri ya da betimlemeleri kullanmaktan kaçınıyorlardı ve bu tanrıları kendi pantheon'larındaki tanrılarla özdeşleştirerek farklı isimlerle anıyorlardı. Bu ifadeye örnek olarak Melkart ile Herakles, Tanit ileyse Hellen Pantheonu'ndaki Hera ve Roma Pantheonu'ndaki luno'nun eşleştirilmesi gösterilebilir. Bu doğrultuda metinde Poseidon olarak belirtilen tanrı da günümüzde net olarak bilinemeyen (Ba'al Sapon?) bir Fenike-Kartaca deniz tanrısının Hellence karşılığı olarak algılanmalıdır. Göz önünde bulundurulması gereken diğer bir önemli husus da Kartacalılar açısından yeterince tanınmayan bir coğrafya olan Afrika'nın kuzeybatı kıyılarına doğru deniz yolculuğuna başlanmadan önce deniz tanrısı adına tapınak inşa edilmesinin ve adakta bulunulmasının beklenmedik bir olgu olmadığıdır. Konu hakkında ayrıca bk. Lurker 1987, 28; Hoyos 2010, 94-100. 
VI. Buradan yelken açınca da büyük bir nehir olan ve de Libya topraklarından denize dökülen Liksos Irmağı'na ${ }^{105}$ ulaştık. Bu nehrin kıyılarında Liksitai olarak bilinen göçmen insanlar sürülerini otlatıyorlardı, onlarla dost olana kadar belirli bir süre onların yanında kaldık.

VII. Bu toprakların iç kesimlerindeyse misafir sevmez Aithiopialılar ikamet etmekteydiler, büyük dağlarla bölünmüş olan topraklarındaysa vahşi hayvanlar yaşamaktaydı. Liksos Irmağı'nın da bu dağlardan aktığı söylenmektedir. Bu dağların eteklerindeyse ilginç görünümlü insanlar olan Troglodytai ${ }^{106}$ (mağara insanları) yaşamaktaydılar. Liksitai halkı onların atlardan bile daha hızlı koştuklarını beyan etmekteydi.

VIII. Onlardan (Liksitai halkından) tercümanlar alarak çorak kıyı boyunca güney istikametinde iki günlük bir sefer yaptık. Oradan da tekrar bir kişinin bir gün boyunca alabileceği yol kadar doğu istikametinde sefere devam ettik. Vardığımız yerdeki bir körfezin ucunda çevresi toplam beş stadia genişliğinde olan küçük bir ada keşfettik. Bu adayı bir kent haline getirerek Kerne ${ }^{107}$ olarak isimlendirdik. Bu adanın deniz yolculuğu bakımından Kartaca'nın tam hizasında (aynı paralelde) uzandığı hükmüne vardık. Öyle ki Kartaca'dan Herakles Sütunları'na ve Herakles

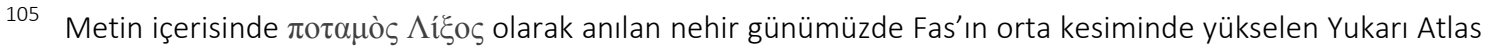
Dağları'nın doruklarından doğan ve yine Fas sahilerinden (Kanarya Adaları karşısından) Atlas Okyanusu'na dökülen Draa Nehri'ne karşılık gelmektedir. Söz konusu nehir aynı zamanda Dra ya da Draâ olarak da telaffuz edilmektedir ve tarihsel kayıtlarda Darha ve Dara Nehri olarak da anılmaktadır. Bu nehrin diğer bir özelliği de yaklaşık 1,100 kilometrelik (680 deniz mili) uzunluğuyla Fas sınırları içerisinde akan nehirlerin en

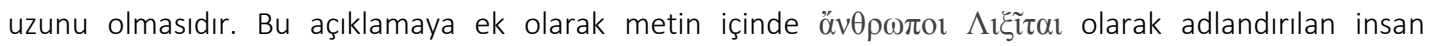
topluluğunun da söz konusu nehrin havzasında ya da denize döküldüğü delta civarında ikamet eden otokton kavimlerin bir uzantısı olduğu düşünülmektedir. Nehrin lokalizasyonu hakkında ayrıca bk. Schoff 2014, 5.

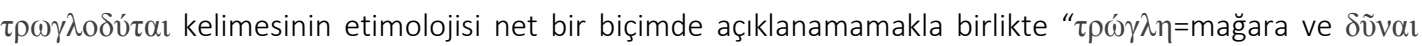
( $\delta$ w $\omega$ fiilinin infinitive active aorist formu) = giriş yapmak, içeri dalmak" kelimelerinden oluşan bir isim-fiil

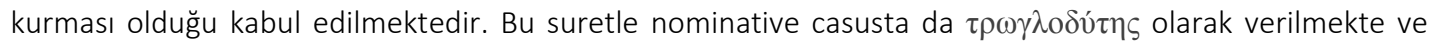
Türkçe karşılı̆̆ını da "Mağaraya girmiş, mağaraya düşmüş, mağara insanı" olarak çevrilmektedir. Bu bilgiler ışığında antikçağ boyunca birçok kavim ve klanın mağaraları ikametgâh olarak (Karain Mağarası'nın Paleolitik Çă̆'dan Roma Dönemi'ne kadar ca. 500.000 yıl boyunca aralıksız olarak kullanım görmüş olması örneğindeki gibi) kullandıkları göz önüne alındığında, Hannon'un karşılaştığı bu insan topluluğunun da bölgedeki mağaralarda yaşayan otokton kavimlere mensup bir grup insan olduğu düşünülmektedir.

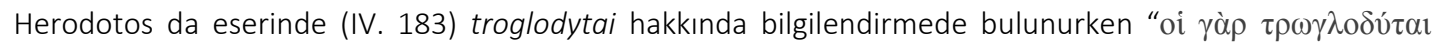

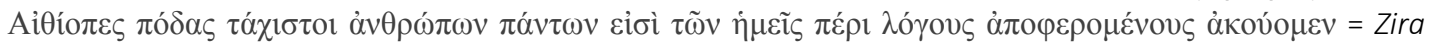
Aithiopialı Troglodytes'ler haklarında bize anlatılan hikâyeleri işittiğimiz kadarıla diğer bütün insanlar arasında en hızlı koşanlardır" tanımlamasını kullanır ve onun bu ifadesi Hannon'un aktarımıyla benzerlik taşır niteliktedir. Bu aktarıma ek olarak Aristoteles de (hist. an. 597A. 9) Troglodytai hakkında bilgilendirmelerde bulunur ve onların farklı coğrafyalarda da (Nil Nehri havzası örneğini kullanarak) aynı isimle anıldığını bildirir. Haklarındaki genel tanımlamaysa bu insanların Afrika'daki Etiyopya topraklarında yaşayan göçebe kavimler oldukları ve oldukça savaşçı bir yapıda olup savaşırlarken silah olarak yalnızca sapan ve taş kullandıkları ve de farklı ulusların ordularında paralı asker olarak savaştıkları yönündedir. Troglodytai hakkında ayrıca bk. Morgan 1989, 534; Higgins 2014, 543-544. hemen kuzeyinde yer almaktadır. Konu hakkında ayrıca bk. Casson 1991, 121-122; Schoff 2014, 5. 
Sütunları'ndan da Kerne'ye olan deniz yolculuğu güzergâhı da aynıdır (benzerdir).

IX. Buradan da geniş bir nehir boyunca ilerleyerek Khretes adında bir göle ulaştık. Bu gölün içerisinde Kerne Adası'ndan daha büyük olan üç tane ada vardı. Buradan (adalardan) itibaren bir günlük bir deniz seferi yaptıktan sonra yolculuğu sona erdirerek gölün diğer ucuna ulaştık. Bu gölün üzerinde hayvan postuna bürünmüş olan yaban insanlarla dolu yüksek dağlar uzanmaktaydı, onlar taşlar atmak suretiyle bizleri kendilerinden uzak tuttular, karaya ayak basmamızı da engellediler.

X. Oradan da yelken açarak timsahlarla ve de su aygırılarıyla dolu büyük ve geniş başka bir nehre ulaştık. Buradan da tekrar geriye dönerek Kerne'ye vardık.

XI. Oradan da güneye doğru kıyıyı takip ederek on iki gün süresince denizde yol aldık, (geçmiş olduğumuz) bu kıyılarda Aithiopia'ılılar ikamet etmekteydiler ve hem bizden kaçıyorlar hem de sabit bir yerde durmuyorlardı. Onlar beraberimizdeki Liksitai halkı için bile anlaşılmaz olan şeyler (farklı bir dilde) konuşuyorlardı.

XII. Sonuncu gündeyse sık ağaçlarla kaplı büyük dağların yakınında demirledik. Bu dağdaki ağaçların kütükleri güzel kokuluydu ve farklı farklıydı.

XIII. Bu dağların etrafında iki gün boyunca yol aldıktan sonra karaya doğru olan tarafında bir ovanın uzandığı uçsuz bucaksız bir körfeze vardık. Geceleyin buralarda belirli mesafelerle her yerde ortaya çıkan ve kâh daha büyük kâh da daha küçük ateşler gördük.

XIV. Oradan su aldıktan sonra büyük bir körfeze varıncaya kadar sahilin önündeki hat boyunca beş günlük yol aldık, tercümanlar bu körfezin Batının Boynuzu olarak adlandırıldığını söylediler. Bu körfezde büyük bir ada, bu adadaysa deniz suyundan meydana gelmiş olan bir göl vardı ve bu gölün içerisinde de başka bir ada daha vardı. Gündüz vakti bu adaya ayak bastığımızda hiçbir şey göremedik, ağaçık bir alan dahi yoktu, ancak geceleyin yanmakta olan birçok ateş gördük. Ayrıca hem flüt hem de tef seslerini, davul gümlemelerini ve çok yoğun uğultuları da işittik. O vakit korkuya kapıldık ve rahipler bize adayı terk etmemizi salık verdiler.

XV. (Oradan) çabucak yelken açtıktan sonra tütsülerle dolu bu alevli toprakları transit geçtik. Buralardan (sahilin üzerinden) muazzam büyüklükteki volkanik lav dalgaları denize akmaktaydı. Sıcaklık sebebiyle sahil (kara) ayak basılmaz durumdaydı.

XVI. O zaman korkmuş bir biçimde oradan da ivedi bir şekilde yelken açtıktan sonra dört günlük bir sefer yapmıştık ki, geceleyin alevle kaplı bir kara parçası gördük. Ortasındaysa yüksek bir alev vardı, diğer alevlerden daha büyüktü, sanki yıldızlara erişiyormuş gibi görünüyordu. Gündüz oluncaysa (alevin olduğu) bu yerin Tanrıların Arabası ${ }^{108}$ olarak adlandırılan oldukça yüksek bir dağ olduğu ortaya çıktı. 
XVII. Buradaki volkanik lav akıntılarını arkamızda bırakmamızın üç gün sonrasındaysa Güneyin Boynuzu olarak adlandırılan koya vardık.

XVIII. Bu koyun ucundaysa tıpkı önceki adayı andıran ve içinde bir göl olan bir ada vardı. Bu gölün içindeyse başka bir ada (daha) mevcuttu ve yaban insanlarla doluydu. Kadınlar açık arayla daha büyük bir çoğunluğa sahipti, vücutlarındaysa kıllar vardı. Tercümanlar bu kadınları Goriller ${ }^{109}$ olarak adlandırıyordu. Erkekleriyse takip etmiş olmamıza rağmen ele geçirmemiz mümkün olmadı zira hepsi tepelere tırmanarak ve de taşlarla kendilerini savunarak kaçtılar. (Yakalanan) üç kadın ise, kendilerini götürenleri hem ısırmak ve hem de tırmalamak suretiyle onlarla gitmek istemiyorlardı. Lakin bu kadınları öldürerek derilerini yüzdük ve yüzdüğümüz derileri de Kartaca'ya götürdük ${ }^{110}$. Artık erzağımız da bizi idare edemeyecek durumda olduğundan dolayı daha da ileriye yelken açamadık...

diğer anlamı dikkate alınarak (daha az ileri sürülen bir tanımlama önerisi olan) Tanrıların Desteği/ Lütfu anlamlarını vermektedir. Hennig $\left(1944^{2}, 93\right)$ ise söz konusu dağın aslında $\theta \varepsilon \tilde{\omega} v$ ő̌́ $\eta \mu \alpha$ (Tanrıların ikametgâhı) olarak isimlendirildiğini ve bir aktarım ya da tercüme hatası sebebiyle söz konusu forma dönüştüğünü belirtir. Buna ek olarak sözü edilen dağın metinden elde edilen bilgiler ışığında volkanik bir dağ olduğu da ileri sürülmektedir ve bu doğrultuda volkanik dağın günümüzdeki lokalizasyonu için iki farklı öneri mevcuttur. Bu önerilerden ilki Gine sınırıları içerisinde yer alan Kakoulima Dağı'nı işaret ederken, ikincisiyse Kamerun sınırları içerisindeki Kamerun Dağı'nın bahsi geçen dağ olabileceğini ileri sürmektedir. Bu iki öneriden ikincisi araştırmacılar tarafından sıklıkla kabul gören bir görüştür. Zira iki volkanik dağdan biri olan Kakoulima Dağı'nın Hannon'un sefere çıkmasından çok uzun bir süre önce sönmüş olduğu bilinmektedir. Kamerun Dağı ise günümüzde de halen aktif bir volkandır ve en son 2000 yılında patlamıştır. Diğer taraftan, Kamerun dağı bölgede ikamet eden yerlilerin kullandıkları dilde "Monga ma Loba" olarak adlandırılmaktadır ve onların dağ için kullandıkları bu ifade Tanrıların Mekânı anlamına gelmektedir. Bu doğrultuda da Theon Okhema Dağı'nın lokalizasyonu için Kamerun Dağı'nın tercih edilmesi daha yüksek bir kabülü beraberinde getirmektedir. Okhema kelimesi için etimolojik açıdan benzer bir kullanım da Euripides'in Troyalı Kadınlar isimli eserinde (Eur. Tro. 884) bulunmaktadır. Euripides anlatısı içinde baş tanrı

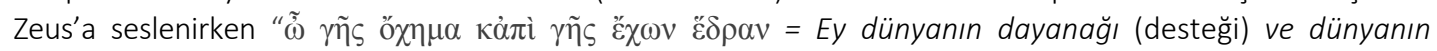
üzerindeki tahta sahip olan" tanımlamasını kullanmaktadır. Bk. dn. 95.

110 Yaşlı Plinius da (nat. VI. 200) "duarumque Gorgadum cutes argumenti et miraculi gratia in lunonis templo posuit spectatas usque ad Carthaginem captam = Ve (Hanno) Kartaca fethedilene kadar görünürde kalmış olan iki yerli kadına ait derileri (seyahatinin) ispatı ve de mucizeviliğinin şükranı olarak luno Tapınağı'na adadı" şeklinde beyanatta bulunur. Onun bu ifadesi söz konusu adağın kendi döneminde de bilindiğine dair kanıt oluşturmaktadır. Hannon'un karşılaştığı ve goril olarak adlandırdığı kadınların aslında Şempanze ya da Babun türündeki bir hayvan topluluğu olabileceği konusundaki karşıt görüş hakkında ayrıca bk. Du Chaillu 1861, 391-395. 


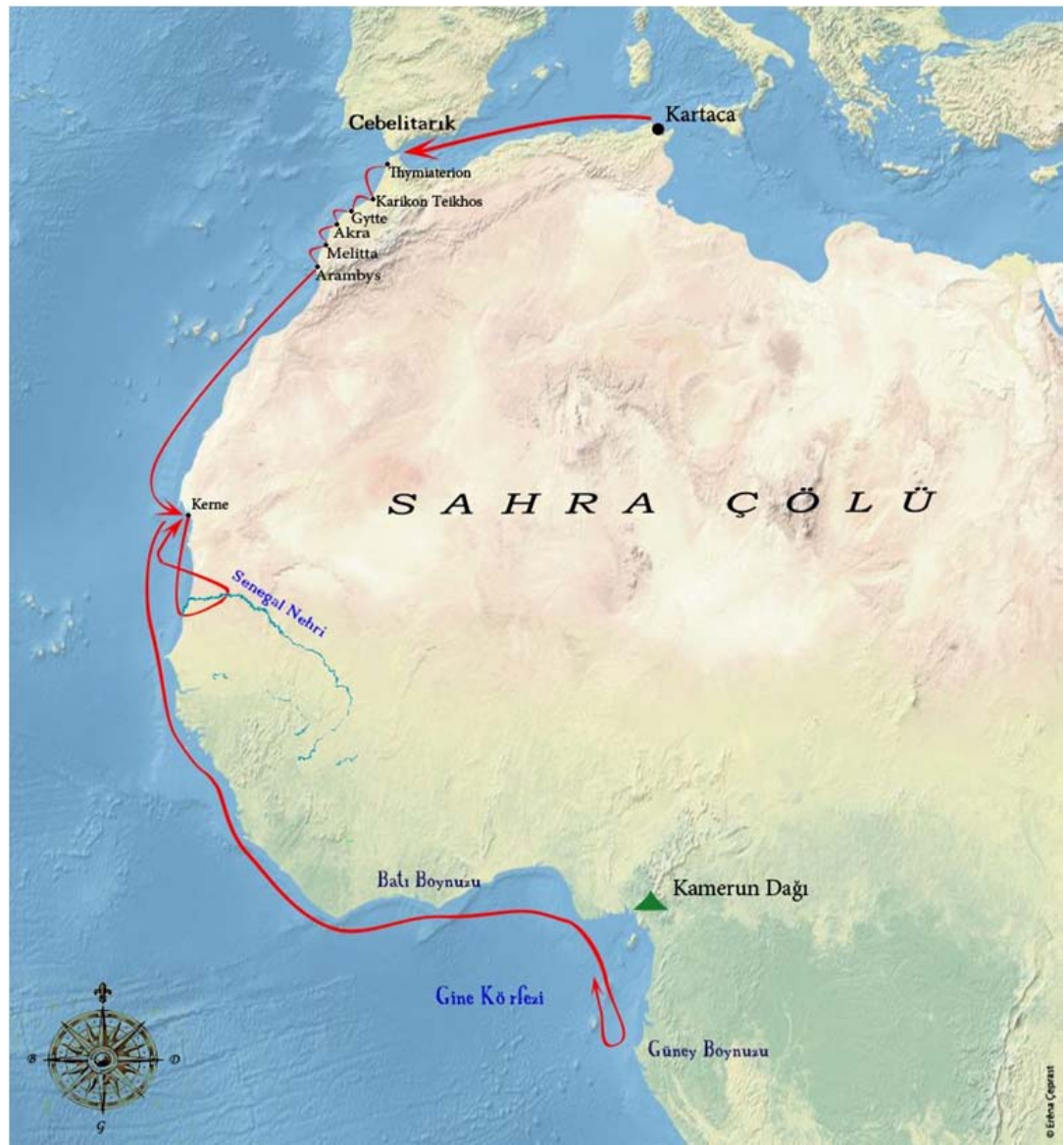

Fig. 1. Hannon'un Seyir Güzergâhını Gösteren Harita

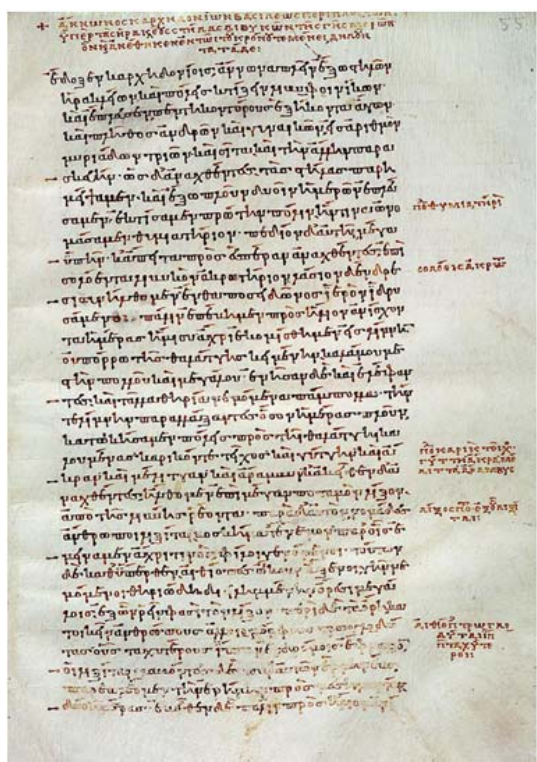

Fig. 2. Heidelberg Üniversitesi Kütüphanesi Arşivinde Bulunan ve M.S. IX. Yüzyıl Sonlarına Tarihlendirilen Codex Palatinus Graecus Manuscript Serisindeki 398 Numaralı Hannon ve Keşif Seferini içeren El Yazması (Kaynak:http://digi.ub.uniheidelberg.de/diglit/cpgraec398/0113). S. 1 


\section{BIBLIYOGRAFYA}

\section{Antik Kaynaklar}

Anonym. Nom. Rhod.

Aristot. Mir. Ausc.

Aristot. hist. an.

Aristot. Pol

Arr. Ind

Avien. Ora Maritima

Cic. Leg. Agr.

Cic. rep.

Dig.

Diog. Laert.

Dion. Hal. Ant.

Eur. Tro.
(= Anonymos, Nomos Rhodion Nautikos)

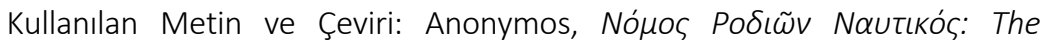
Rhodian Sea Law. Ed. \& Trans.: W. Ashburner. Oxford 1909. Rhodos'luların Denizcilik Yasası. Çev.: E. Kurul. Cedrus II (2014) 527-549.

(= Aristoteles, Mirabilium Auscultationes)

Kullanılan Metin ve Çeviri: Aristoteles, Minor Works: On Marvellous Things Heard. Trans.: W. S. Hett, vol. XIV. Cambridge, Massachusetts - London $1955^{2}$ (The Loeb Classical Library).

(= Aristoteles, Historia Animalium)

Kullanılan Metin ve Çeviri: Aristoteles, History of Animals, Books VII-X. Trans.: D. M. Balme, vol. XI. Cambridge, Massachusetts - London 1991 (The Loeb Classical Library).

(= Aristoteles, Politika)

Kullanılan Metin ve Çeviri: Aristoteles, Politica. Trans.: H. Rackham, vol. XXI. Cambridge, Massachusetts - London $2005^{10}$ (The Loeb Classical Library). (= Arrianus, Historia Indica)

Kullanılan Metin ve Çeviri: Arrian, Indica. Trans.: P. A. Brunt. Cambridge, Massachusetts - London $2000^{3}$ (The Loeb Classical Library).

(= Rufius Festus Avienus, Ora Maritima)

Kullanılan Metin ve Çeviri: Rufi Festi Avieni, Ora Maritima. Ed. \& Trans.: S. Wilhelm. Berlin 1855.

(= Cicero, De Lege Agraria)

Kullanılan Metin ve Çeviri: Cicero, Pro Quinctio. Pro Roscio Amerino. Pro Roscio Comoedo. On the Agrarian Law. Trans.: J. H. Freese, vol. VI. Cambridge, Massachusetts - London 1930 (The Loeb Classical Library).

(= Cicero, De Re Publica)

Kullanılan Metin ve Çeviri: Cicero, On The Republic, On the Laws. Trans.: C. W. Keyes, vol. XVI. Cambridge, Massachusetts - London 1928 (The Loeb Classical Library).

(= Iustinianus, Corpus Iuris Civilis, Digesta)

Kullanılan Metin ve Çeviriler: Digesta Iustiniani Augusti. Eds.: T. Mommsen - P. Krüger, vol. I. Berlin 1870.

Iustinianus, Digesta XIV. 2: Gemiden Mal Atımına Iliş̧kin Rhodos Yasası Hakkında. Çev.: E. Kurul. Cedrus III (2015) 379-389.

(= Diogenes Laertios)

Kullanılan Metin ve Çeviriler: Lives of Eminent Philosophers. Trans.: R. D. Hicks, vol. II. Cambridge, Massachusetts - London $1931^{2}$ (The Loeb Classical Library).

Diogenes Laertios, Ünlü Filozofların Yaşamları ve Öğretileri. Çev.: C. Şentuna. İstanbul $2013^{5}$.

(= Dionysios Halikarnassos, De Antiquitates Romanae)

Kullanılan Metin ve Çeviri: Dionysius of Halicarnassus, The Roman Antiquites. Trans.: E. Cary. Cambridge, Massachusetts $1960^{3}$ (The Loeb Classical Library).

(= Euripides, Troiades)

Kullanılan Metin ve Çeviri: Euripides, Trojan Women. Iphigenia among the Taurians. Ion. Trans.: D. Kovacs, vol. IV. Cambridge, Massachusetts - 
FGrHist

Hdt.

Hom. II.

Hom. Od.

Hydat.

Isokr. Nik.

lust.

Mela.

Plat. Phaedo

Plaut. Poen.

Plin. nat

Plut.

Polyb.
London 1990 (The Loeb Classical Library).

(= Die Fragmente der Griechischen Historiker)

Kullanılan Metin: Die Fragmente der Griechischen Historiker. Ed. F. Jacoby I-XV. Berlin - Leiden 1923 - 1958.

(= Herodotos, Historiai)

Kullanılan Metin ve Çeviriler: Herodotos, The Persian Wars. Trans.: A. D. Godley, vol. I-IV. Cambridge, Massachusetts - London 1920-2004 ${ }^{12}$ (The Loeb Classical Library).

Herodotos, Tarih. Çev.: M. Ökmen. İstanbul $1991^{3}$.

(= Homeros, ilyada)

Kullanılan Metin ve Çeviri: Homeros, Ilyada. Çev.: A. Erhat - A. Kadir. İstanbul $1993^{7}$.

(= Homeros, Odysseia)

Kullanılan Metin ve Çeviri: Homeros, Odysseia. Çev.: A. Erhat - A. Kadir. İstanbul $1988^{6}$.

(= Hydatius, Continuatio Chronicorum Hieronymianorum)

Kullanılan Metin: Hydatius, Continuatio Chronicorum Hieronymianorum.

Ed. T. Mommsen, Monumenta Germaniae Historica, Auctores Antiquissimi 11: Chronica Minora Saec. IV. V. VI. VII, Volume II. Berlin (1894) 1-36.

(= Isokrates, Nikokles or Kyprioi])

Kullanılan Metin ve Çeviri: Isocrates, To Demonicus. To Nicocles. Nicocles or the Cyprians. Panegyricus. To Philip. Archidamus. Trans.: G. Norlin, vol. I. Cambridge - Massachusetts - London 1928 (The Loeb Classical Library).

(Marcus Iulianus lustinus, M. Iuliani Iustini Epitoma Historiarum Philippicarum Pompei Trogi)

Kullanılan Metin ve Çeviri: Justin, Epitome of the Philippic History of Pompeius Trogus. Trans.: J. C. Yardley. Intr.: R. Develin. Atlanta, GA 1994.

(= Pomponius Mela, De Chorographia)

Kullanılan Metin ve Çeviri: Pomponius Mela's Description of the World. Trans.: F. E. Romer. Ann Arbor 1998.

(= Platon, Phaedo)

Kullanılan Metin ve Çeviri: Plato, Euthyphro, Apology, Crito, Phaedo, Phaedrus. Trans.: H. N. Fowler, vol. I. London - New York 1913 (The Loeb Classical Library).

(= Titus Maccius Plautus, Poenulus)

Kullanılan Metin ve Çeviri: Plautus, The Little Carthaginian. Pseudolus. The Rope. Trans.: W. De Melo, vol. IV. Cambridge, Massachusetts - London 2012 (The Loeb Classical Library).

(= Gaius Plinius Secundus "Yaşlı", Naturalis Historia)

Kullanılan Metin ve Çeviri: Gaius Plinius Secundus, Natural History. Trans.:

H. Rackham, vol. I-V. Cambridge, Massachusetts - London $1961^{3}-1999^{6}$

(The Loeb Classical Library).

(= Plutarkhos, Bioi Paralleloi)

Caes. (= Caesar) Pomp. (= Pompeius)

Kullanılan Metin ve Çeviri: Plutarkhos, Plutarch's Lives. Trans.: B. Perrin, vol II-VI. Cambridge, Massachusetts - London 1954³ - 1968 (The Loeb Classical Library).

(= Polybios, Historiai)

Kullanılan Metin ve Çeviri: Polybius, The Histories. Trans.: W. R. Paton, vol. II-III-VI. Cambridge, Massachusetts - London 2010-2012 (The Loeb Classical 
Proc. de Bell.

R. Gest. div. Aug.

Sen. Nat

Skylaks periplus

Solin.

Steph. Byz. Ethnika

Strab.

Suet. Aug.

Vell.

Victor Vit. Hist. Pers.

\section{Modern Literatür}

Abulafia 2012

Ameling 2011

Arslan 2010

Arslan 2012
Library).

(= Procopius, de Bellis)

Kullanılan Metin ve Çeviri: Procopius, History of the Wars. Trans.: H. B. Dewing, vol. II. Cambridge, Massachusetts - London 1916 (The Loeb Classical Library).

(= Augustus, Res Gestae Divi Augusti)

Kullanılan Metin ve Çeviri: Velleius Paterculus, Compendium of Roman History, Res Gestae Divi Augusti. Trans.: W. Shipley. Cambridge Massachusetts $1961^{3}$ (The Loeb Classical Library)

(= Seneca Minor, Naturales Questiones)

Kullanılan Metin ve Çeviri: Seneca, Natural Questions, Books IV-VII. Trans.:

C. H. Corcoran, vol. II. Cambridge, Massachusetts - London 1972 (The Loeb Classical Library).

(= Skylaks, Periplus Scylacis)

Kullanılan Metin ve Çeviri: Scylaks, Periplus Scylacis. Ed. K. Müller, Geographi Graeci Minores, vol. I. Paris $\left(1990^{2}\right)$ 15-96.

Pseudo-Skylaks: Periplus. Çev.: M. Arslan. MJH II/1 (2012) 239-257.

(= Gaius Iulius Solinus, Polyhistor)

Kullanılan Metin ve Çeviri: Gaius Iulius Solinus, Polyhistor. Trans.: M. A. Agnant. Paris 1847

(= Stephanos Byzantios, Ethnika)

Kullanılan Metin: Stephanos Byzantios, Stephani Byzantii, Erhnikon. Ed. A. Westermann. Lipsiae 1839.

(= Strabon, Geographika)

Kullanılan Metin ve Çeviri: Strabon, The Geography of Strabo. Trans.: H. L. Jones, vol. I. London - New York 1917 (The Loeb Classical Library).

(=Suetonius, De Vitae Caesarum, Divus Augustus)

Kullanılan Metin ve Çeviriler: Suetonius, The Lives of the Caesars. Trans.: J.

C. Rolfe, vol. I. London - New York 1914 (The Loeb Classical Library).

Gaius Suetonius Tranquillus, On Iki Caesar'ın Yaşamı. Çev.: F. Telatar - G. Özaktürk. Ankara 2008.

(= Velleius Paterculus, Historia Romana)

Kullanılan Metin ve Çeviri: Velleius Paterculus, Compendium of Roman History, Res Gestae Divi Augusti. Trans.: W. Shipley. Cambridge - Massachusetts $1961^{3}$ (The Loeb Classical Library).

(= Victor Vitensis, Historia Persecutionis Africanae Provinciae)

Kullanılan Metin ve Çeviri: Victor of Vita, History of the Vandal Persecution. Trans. \& Intro.: J. Moorhead. Liverpool 1992.

D. Abulafia, Büyük Deniz, Akdeniz'de Insanlık Tarihi. Çev. G. Ç. Güven. istanbul 2012.

W. Ameling, "The Rise of Carthage to 264 BC". Ed. D. Hoyos, A Companion to the Punic Wars. Malden - Oxford (2011) 39-57.

M. Arslan, Istanbul'un Antikçağ Tarihi: Klasik ve Hellenistik Dönemler. İstanbul 2010.

M. Arslan, "Pseudo-Skylaks: Periplous". MJH II/1 (2012) 239-257.

http://dx.doi.org/10.13114/MJH/20122783 
Asente 2015

Aubet 2001

Bagnall 2002

Bayer 1993

Bell 1836

Berkelius 1674

Bevan 1859

Bianchetti 1999

Blomqvist 1979

Börstinghaus 2010

Bradford 2013

Branigan 1994

Braudel 2007

Brodersen 1998a

Brodersen 1998b

Bunbury 1879

Burns $1968^{7}$

Cary - Warmington 1929

Casson $1979^{2}$

Casson 1991

Casson 2002

Cavendish 2005

CEDRUS

Clifford 1990

Conner 2012

Crawford - Whitehead 1983
M. K. Asente, The History of Africa: The Quest for Eternal Harmony. New York 2015.

M. E. Aubet, The Phoenicians and the West: Politics, Colonies and Trade. Cambridge - New York $2001^{2}$.

N. Bagnall, The Punic Wars 264-146 B.C. Oxford 2002.

K. Bayer, "Periplus Hannonis". Eds. G. Winkler - R. König, Gaius Plinius Secundus d. Ä.: Naturkunde (Historia Naturalis), Lateinisch - Deutsch: Buch V, Geographiae; Afrika und Asien. Zürich-München (1993) 346-353.

J. Bell, A System of Geography, Popular and Scientific: Or A Physical, Political and Statistical Account of the World and Its Various Divisions, volume VI. London 1836.

A. Berkelius, Genuina Stephani Byzantini De Urbibus Et Populis Fragmenta: Abrahamus Berkelius Latinam Interpretationem et Animadversiones Adiecit; Accedit Hannonis Carthaginensium Regis Periplus Graece et Latine. Leiden 1674.

W. L. Bevan, A Manual of Geographical Science, Mathematical, Physical, Historical and Descriptive. London 1859.

S. Bianchetti, "Reiseberichte". Ed. H. Sonnabend, Mensch und Landschaft in der Antike: Lexikon der Historischen Geographie. Stuttgart - Weimar (1999) 420-423.

J. Blomqvist, The Date and Origin of the Greek Version of Hanno's Periplus: With an Edition of the Text and a Translation. Lund 1979.

J. Börstinghaus, Stumfahrt und Schiffbruch. Tübingen 2010.

E. Bradford, Akdeniz: Bir Denizin Hikâyesi. Çev. A. Fethi. İstanbul 2013.

C. Branigan, "The Circumnavigation of Africa". Classics Ireland I (1994) 13.

F. Braudel, Bellek ve Akdeniz, Tarihöncesi ve Antikçağ. Çev. A. Berktay. İstanbul 2007.

K. Brodersen, "Hanno". Der Neue Pauly: Enzyklopädie der Antike V (1998) 155.

K. Brodersen, "Euthymenes aus Massalia". Der Neue Pauly: Enzyklopädie der Antike IV (1998) 318-319.

E. H. Bunbury, History of Ancient Geography Among the Greeks and Romans from the Earliest Ages till the Fall of the Roman Empire. London 1879.

E. N. Burns, Western Civilizations: Their History and Their Culture. New York $1968^{7}$

M. Cary - E. H. Warmington, The Ancient Explorers. London 1929.

L. Casson, Travel in the Ancient World. London $1979^{2}$.

L. Casson, The Ancient Mariners: Seafarers and Sea Fighters of the Mediterranean in Ancient Times. Princeton 1991.

L. Casson, Antik Çağda Denizcilik ve Gemiler. Çev.: G. Ergin. İstanbul 2002. M. Cavendish, Explorers and Exploration. New York 2005. Akdeniz Uygarlıkları Araştırma Dergisi. Antalya 2013-.

R. J. Clifford, "Phoenician Religion". Bulletin of the American Schools of Oriental Research 279 (1990) 55-64.

C. D. Conner, Halkın Bilim Tarihi: Madenciler, Ebeler ve "Basit Tamirciler". Çev.: Z. Ç. Kanburoğlu. Ankara 2012.

M. Crawford - D. Whitehead, Archaic and Classical Greece: A Selection of Ancient Sources in Translation. Cambridge - New York 1983. 
Culican $2003^{5}$

Daebritz 1912

Davis 2009

Demerliac - Meirat 1983

Diller 1952

Demetriou 2012

Du Chaillu 1861

Dürüşken 2009

Eck $2007^{2}$

Edmondson 2006

Eichel - Todd 1976

Falconer 1797

Fishwick 1993

Forbiger 1877

Freeman $2013^{4}$

Gasparini 2015

Gelenius 1533

Geus 1994

Goldsworthy 2000

Gould $2011^{2}$

Gruen $2004^{3}$

Gutschmidt 1891

Haas 1985

Hansen 1997
W. Culican, "Phonicia and Phonician Colonization". Eds J. Boardman - I. E. S. Edwards et al., The Cambridge Ancient History III/2. Cambridge - New York $\left(2003^{5}\right)$ 461-546.

R. Daebritz, "Hanno". Realencyclopädie der Classischen Altertumswissenschaft VII. 2 (1912) 2360-2363.

D. L. Davis, Commercial Navigation in the Greek and Roman World. Unpublished Doctoral Dissertation, The University of Texas. Austin 2009.

J. G. Demerliac - J. Meirat, Hannon et l'Empire Punique. Paris 1983.

A. Diller, The Tradition of the Minor Greek Geographers. Lancester Oxford 1952.

D. Demetriou, Negotiating Identity in the Ancient Mediterranean: The Archaic and Classical Greek Multiethnic Emporia. Cambridge - New York 2012.

P. B. Du Chaillu, Explorations and Adventures in Equatorial Africa. New York 1861.

Ç. Dürüşken, Caesar Augustus, Ankara Anıtı: Monumentum Ancyranum. İstanbul 2009.

W. Eck, The Age of Augustus. Trans. D. L. Schneider. Malden - Oxford Victoria $2007^{2}$.

J. Edmondson, "Cities and Urban Life in the Western Provinces of the Roman Empire, 30 BCE-250 CE". Ed. D. S. Potter, A Companion to the Roman Empire. Malden - Oxford (2006) 250-280.

M. H. Eichel - J. M. Todd, "A Note on Polybius' Voyage to Africa in 146 B.C.". Classical Philology 71/3 (1976) 237-243.

T. Falconer, The Voyage of Hanno, Translated and Accompanied with the Greek Text. London 1797.

D. Fiswick, "On the Rrigins of Africa Proconsularis, I: The Amalgamation of Africa Vetus and Africa Nova". Antiquités Africaines 29 (1993) 53-62.

A. Forbiger, Handbuch der Alten Geographie, Erster Band, Zweite Ausgabe. Hamburg 1877.

C. Freeman, Mısır, Yunan ve Roma: Antik Akdeniz Uygarlıkları. Çev. S. K. Angı. İstanbul $2013^{4}$.

V. Gasparini, "Tracing Religious Change in Roman Africa". Eds. R. Raja - J. Rüpke, A Companion to the Archaeology of Religion in the Ancient World. Malden - Oxford (2015) 478-488.

S. Gelenius, Arriani et Hannonis Periplus. Plutarchus de Fluminibus et Montibus. Strabonis Epitome. Basel 1533.

K. Geus, Prosopographie der Literarisch Bezeugten Karthager. Leuven 1994. A. Goldsworthy, The Fall of Carthage, The Punic Wars 265-146 BC. London 2000.

R. A. Gould, Archaeology and the Social History of Ships. Cambridge $2011^{2}$. E. S. Gruen, "The Expansion of the Empire under Augustus". Eds. A. K. Bowman - E. Champlin - A. Lintott, The Cambridge Ancient History X. Cambridge - New York $\left(2004^{3}\right)$ 147-197.

A. von Gutscmidt, "Die Heidelberger Handschrift der Paradoxographen (Pal. Gr. 398)". Neue Heidelberger Jahrbücher Jahrgang I (1891) 227-237.

C. J. Haas, "Athenian Naval Power Before Themistocles". Historia: Zeitschrift für Alte Geschichte 34/1 (1985) 29-46.

M. H. Hansen, "Emproion. A Study of the Use and Meaning of the Term in the Archaic and Classical Periods". Ed. T. H. Nielsen, Yet More Studies in 
Hansen 2006

Hair 1987

Heenan 1996

Hennig 1927

Hennig $1944^{2}$

Higgins 2014

Hitchner 2010

Howatson 2013

Hoyos 2007

Hoyos 2010

Hudson 1698

Huß 1985

Huß 1990

Irby 2012

Irby-Massie - Keyser 2002

Kaplan 2012

Kingsley 2010

Kitchell 1998

Kurul 2014

Kurul 2015

Küppers 1997

Lamboley 2007

Landels 1997

Law $2002^{7}$

Lee 2013 the Ancient Greek Polis, Volume II. Stuttgart (1997) 83-106.

M. H. Hansen, Polis: An Introduction to the Ancient Greek City-State. Oxford - New York 2006.

P. E. H. Hair, "The Periplus of Hanno in the History and Historiography of Black Africa". History in Africa 14 (1987) 43-66.

P. Heenan, "Carthage (Tunis, Tunisia)". Eds. K. A. Berney, S. La Boda - R. M. Salkin, International Dictionary of Historic Places: Middle East and Africa: Volume 4. Chicago - London (1996) 177-181.

R. Hennig, "Hannos "Götterwagen". Geographische Zeitschrift 33/7 (1927) 378-392.

R. Hennig, Terrae Incognitae, Volume I, Altertum bis Ptolemaus. Leiden $1944^{2}$.

D. M. Higgins, "Troglodyte". Ed. J. Weinstock, The Ashgate Encyclopedia of Literary and Cinematic Monsters. Farnham - Burlington (2014) 543-544.

R. B. Hitchner, "Africa, Province of". Ed. M. Gagarin, The Oxford Encyclopedia of Ancient Greece and Rome I. Oxford (2010) 34-37.

M. C. Howatson, Oxford Antikçağ Sözlüğü. Çev. F. Ersöz. İstanbul 2013.

D. Hoyos, Truceless War: Carthage's Fight for Survival, 241 to 237 BC. Leiden - Boston 2007.

D. Hoyos, The Carthaginians. London - New York 2010.

J. Hudson, Geographiae Veteris Scriptores Graeci Minores: Cum Interpretatione Latina, Dissertationibus, ac Annotationibus. Vol. 1. Oxoniae 1698.

W. Huß, Geschichte der Karthager. München 1985.

W. Huß, Die Karthager. München 1990.

L. Irby, "Mapping the World. Greek Initiatives from Homer to Eratosthenes". Ed. R. J. A. Talbert, Ancient Perspectives: Maps and Their Place in Mesopotamia, Egypt, Greece and Rome. London (2012) 81-108.

G. L. Irby-Massie - P. T. Keyser, Greek Science of the Hellenistic Era: A Sourcebook. London - New York 2002.

P. Kaplan, "Hanno the Navigator". Eds. E. K. Akyeampong - H. L. Gates, Dictionary of African Biography, Volume III. Oxford - New York (2012) 2426.

M. Kingsley, West African Studies. Cambridge - New York 2010.

K. F. Kitchell, "Hanno". Ed. F. N. Magill, Dictionary of World Biography, Volume I: The Ancient World. California - Chicago - London (1998) 488-492.

E. Kurul, "Rhodos'luların Denizcilik Yasası". Cedrus II (2014) 527-549. http://dx.doi.org/10.13113/CEDRUS.201406473

E. Kurul, "Iustinianus, Digesta XIV. 2: Gemiden Mal Atımına Illişkin Rhodos Yasası Hakkında". Cedrus III (2015) 379-389. http://dx.doi.org/10.13113/CEDRUS.2015011409

J. Küppers, "Avienus". Der Neue Pauly: Enzyklopädie der Antike 2 (1997) 370-371.

J. L. Lamboley, "Migration and Greek Civilization". Ed. A. K. Isaacs, Immigration and Emigration in Historical Perspective. Pisa (2007) 55-64.

J. G. Landels, Engineering in the Ancient World. London 1997.

R. C. C. Law, "North Africa in the Period of Phoenician and Greek Colonization, c. 800 to 323 BC". Ed. J. D. Fage, The Cambridge History of Africa, Volume II. Cambridge (2002 ${ }^{7}$ ) 87-148.

A. D. Lee, From Rome to Byzantium AD, 363 to 565: The Transformation of Ancient Rome. Edinburgh 2013. 
Leone 2007

Lipiński 2004

Lurker 1987

Mahan 2011

Mahan 2013

Mahjoubi 1981

Marindin 1910

Meijer - van Nijf 1992

Mills 2003

Mitchell 1850

Mommsen 1908

Moore 2010

Morgan 1989

Morrison - Coates $1987^{2}$

Moscati 2004

Mosley 1975

Mullerus 1990

Mund-Dopchie 1994

Mund-Dopchie 2003

Osborne 1997

Öngör 1954

Pohl 2005

Purcell 1995

Purcell 2013
A. Leone, Changing Townscapes in North Africa from Late Antiquity to the Arab Conquest. Bari 2007.

E. Lipiński, Itineraria Phoenicia. Leuven 2004.

M. Lurker, The Routledge Dictionary of Gods and Goddesses, Devils and Demons. London - New York 1987.

A. T. Mahan, Deniz Gücünün Tarih Üzerine Etkisi, 1660-1783. Çev.: A. T. Büyükonat. İstanbul 2011.

A. T. Mahan, Deniz Harbi Üzerine, Tuğa. A. T. Mahan'ın Kitaplarından Seçmeler. Çev.: A. T. Büyükonat. İstanbul 2013.

A. Mahjoubi, "The Roman and Post-Roman Period in North Africa". Ed. G. Mokhtar, General History of Africa II: Ancient Civilizations of Africa. California (1981) 465-512.

G. E. Marindin, A Smaller Classical Dictionary of Biography, Mythology and Geography. London 1910.

F. Meijer - O. van Nijf, Trade, Transport and Society in the Ancient World: A Sourcebook. London - New York 1992.

W. J. Mills, Exploring Polar Frontiers: A Historical Encyclopedia, Volume II. California 2003.

A. S. Mitchell, Mitchel's Ancient Geography. Philadelphia 1850.

T. Mommsen, The History of Rome. Trans.: W. P. Dickson. New York 1908.

J. P. Moore, "Carthage". Ed. M. Gagarin, The Oxford Encyclopedia of Ancient Greece and Rome II. Oxford (2010) 53-55.

J. R. Morgan, "Heliodorus, An Ethiopian Story". Ed. B. P. Reardon, Collected Ancient Greek Novels. Los Angeles - London (1989) 349-588.

J. S. Morrison - J. F. Coates, The Athenian Trireme. Cambridge $1987^{2}$.

S. Moscati, Fenikeliler. Çev. S. Gül. İstanbul 2004.

D. J. Mosley, Diplomacy in Ancient Greek. London 1975.

C, Mullerus, Geographi Graeci Minores. Hildesheim, Zürich - New York 1990.

M. Mund-Dopchie, "Different Readings of Hanno's Voyage from the Renaissance to the Seventeenth Century: From Pure Erudition to Ideological Debate". Ed. Z. von Martels, Travel Fact and Travel Fiction: Studies on Fiction, Literary Tradition, Scholary Discovery and Observation in Travel Writing. Leiden, New York - Köln (1994) 111-119.

M. Mund-Dopchie, "Hanno". Ed. W. Brown, Catalogus Translationum et Commentariorum Mediaeval and Renaissance Latin Translations and Commentaries. Washington (2003) 49-57.

C. Osborne, "Heraclitus". Ed. C. C. W. Taylor, Routledge History of Philosophy Volume I: From the Beginning to Plato. London - New York (1997) 80-116.

S. Öngör, Coğrafi Keşifler ve Tetkik Seyahatleri Tarihi. İstanbul 1954.

W. Pohl, "Justinian and the Barbarian Kingdoms". Ed. M. Mass, The Cambridge Companion to the Age of Justinian. Cambridge - New York (2005) 448-476.

N. Purcell, "On the Sacking of Carthage and Corinth". Eds. D. C. Innes - H. Hine - C. Pelling, Ethics and Rhetoric: Classical Essays for Donald Russell on His Seventy-Fifth Birthday. Oxford (1995) 133-148.

N. Purcell, "Urbanism". Ed. A. Barchiesi - W. Scheidel, The Oxford Handbook of Roman Studies. Oxford (2013) 579-592. 
Purchas 1625

Ramusio 1550

Riffenburgh 2012

Roller 2006

Roller 2012b

Rostovtzeff 1957

Russell 1945

Salama 1981

Sarton 1993

Savage 1847

Seccombe 1900

Schoff 2014

Schwarcz 2004

Scullard 1955

Scullard 1989

Scullard $2013^{2}$

Shahar 2004

Smith 1877

Starr 2000

Steinby 2014

Tarn 1907

Temporal 1556

Torr 1895

Thomson 1948

Tozer 1971

Tüner Önen 2015
S. Purchas, Purchas his Pilgrimes, In Five Books: or Relations of the World and the Religions Observed in All Ages and Places Discovered, from the Creation unto this Present. London 1625.

G. B. Ramusio, Primo Volume delle Navigationi et Viaggi nel qual si Contiene la Descrittione dell' Africa. Venice 1550.

B. Riffenburgh, Antik Dönemden Günümüze Haritacılar. Çev. Ç. Sunay. İstanbul 2012.

D. W. Roller, Through the Pillars of Herakles Greco-Roman Exploration of the Atlantic. New York - Oxon 2006.

D. W. Roller, "Himilco the Navigator". Eds. E. K. Akyeampong - H. L. Gates, Dictionary of African Biography, Volume III. Oxford - New York (2012) 70-71. M. Rostovtzeff, The Social and Economic History of the Roman Empire: Vol. I-II. Oxford 1957.

B. Russell, A History of Western Philosophy. New York 1945.

P. Salama, "The Sahara in Classical Antiquity". Ed. G. Mokhtar, General History of Africa II: Ancient Civilizations of Africa. California (1981) 513533.

G. Sarton, Ancient Science Through the Golden Age of Greece. New York 1993.

T. S. Savage, "Notice of the External Characteristics and Habits of Troglodytes Gorilla, a New Species of Orang From the Gaboon River". Boston Journal of Natural History 5 (1847) 417-26.

T. Seccombe, "Vossius". Ed. S. Lee, Dictionary of National Biography, Vol. 63. London (1900) 392-396.

W. H. Schoff, The Periplus of Hanno, A Voyage of Discovery Down the West African Coast, by a Carthaginian Admiral of the Fifth Century BC. Philadelphia 2014.

A. Schwarcz, "The Settlement of the Vandals in North Africa". Ed. A. H. Merrills, Vandals, Romans and Berbers: New Perspectives on Late Antique North Africa. Aldershot - Burlington (2004) 49-58.

H. H. Scullard, "Carthage". Greece \& Rome 2/3 (1955) 98-107.

H. H. Scullard, "Carthage and Rome". Eds. F. W. Walbank - A. E. Astin et al., The Cambridge Ancient History VII/2. Cambridge - New York (1989) 486-572.

H. H. Scullard, A History of the Roman World: 753 to 146 BC. Oxford - New York $2013^{2}$

Y. Shahar, Josephus Geographicus. Tübingen 2004.

W. Smith, A Smaller Classical Dictionary of Biography, Mythology and Geography. New York 1877.

C. G. Starr, Antik Çağda Deniz Gücü. Çev. G. Ergin. İstanbul 2000.

C. Steinby, Rome Versus Carthage: The War at Sea. Barnsley 2014.

W. W. Tarn, "The Fleets of the First Punic War". The Journal of Hellenic Studies 27 (1907) 48-60.

J. Temporal, Historiale Description de l'Afrique, Tierce Partie du Monde. Lyon 1556.

C. Torr, Ancient Ships. Cambridge 1895.

J. O. Thomson, History of Ancient Geography. Cambridge 1948.

H. F. Tozer, History of Ancient Geography. New York 1971.

N. Tüner Önen, Plutarkhos, Bioi Paralleloi, Agesilaos \& Pompeius: Giriş, Değerlendirme ve Açıklayıcı Notlar. Antalya 2015. 
Vossius 1658

Warmington 1940

Warmington 1960

Warmington 1981

Warnecke 1999

Watkins 1800

Wolters 1952

Wright $1951^{4}$

Wyatt 2007

Yiğit 2012
I. Vossius, Isaaci Vossii Observationes ad Pomponium Melam De Situ Orbis. London 1658.

E. H. Warmington, "Africa in Ancient and Medieval Times". Eds. J. H. Rose, A. P. Newton - E. A. Benians, The Cambridge History of the British Empire, Volume II: The Growth of the New Empire, 1783-1870. Cambridge - New York (1940) 53-78.

B. H. Warmington, Carthage. London 1960.

B. H. Warmington, "The Carthaginian Period". Ed. G. Mokhtar, General History of Africa II: Ancient Civilizations of Africa. California (1981) 441464.

H. Warnecke, "Schiffahrt". Ed. H. Sonnabend, Mensch und Landschaft in der Antike: Lexikon der Historischen Geographie. Stuttgart - Weimar (1999) 438-442.

J. Watkins, The Universal Biographical Dictionary. London 1800.

E. J. Wolters, "Carthage and its People". The Classical Journal 17/5 (1952) 191-204.

F. A. Wright, Classical Dictionary of Proper Names Mentioned in Ancient Authors. London $1951^{4}$.

N. Wyatt, "Religion in Ancient Ugarit". Ed. J. R. Hinnels, A Handbook of Ancient Religions. Cambridge - New York (2007) 105-160.

i. Yiğit, "Tunus". Türkiye Diyanet Vakfı islâm Ansiklopedisi 41 (2012) 385388. 